\title{
Hypoxia-inducible factor-1 and associated upstream and downstream proteins in the pathophysiology and management of glioblastoma
}

\author{
Matthew Womeldorff, B.S., David Gillespie, Ph.D., and Randy L. Jensen, M.D., Ph.D. \\ Department of Neurosurgery, Huntsman Cancer Institute, University of Utah, Salt Lake City, Utah
}

\begin{abstract}
Glioblastoma multiforme (GBM) is a highly aggressive brain tumor with an exceptionally poor patient outcome despite aggressive therapy including surgery, radiation, and chemotherapy. This aggressive phenotype may be associated with intratumoral hypoxia, which probably plays a key role in GBM tumor growth, development, and angiogenesis. A key regulator of cellular response to hypoxia is the protein hypoxia-inducible factor-1 (HIF-1). An examination of upstream hypoxic and nonhypoxic regulation of HIF-1 as well as a review of the downstream HIF-1regulated proteins may provide further insight into the role of this transcription factor in GBM pathophysiology. Recent insights into upstream regulators that intimately interact with HIF-1 could provide potential therapeutic targets for treatment of this tumor. The same is potentially true for HIF-1-mediated pathways of glycolysis-, angiogenesis-, and invasion-promoting proteins. Thus, an understanding of the relationship between HIF-1, its upstream protein regulators, and its downstream transcribed genes in GBM pathogenesis could provide future treatment options for the care of patients with these tumors.
\end{abstract}

(http://thejns.org/doi/abs/10.3171/2014.9.FOCUS14496)

$\begin{array}{lllll}\text { KEY WoRDS } & \bullet & \text { glioblastoma } \\ \text { metabolism } & \bullet & \text { glycolysis }\end{array}$

$\mathrm{G}$ LIOBLASTOMA multiforme (GBM) is a highly aggressive brain tumor that typically develops treatment resistance and results in poor patient outcome. Most solid tumors, including GBM, are thought to contain regions of hypoxia within the body of the tumor. ${ }^{88}$ One of the hallmarks of GBM is intratumoral necrosis, which is thought to be the result of this hypoxia. As with other tumor types, hypoxia in GBM is implicated in conferring resistance to antiangiogenic therapy, chemotherapy, and radiation therapy, and in developing an aggressive tumor phenotype by increased invasion and loss of apoptotic potential. ${ }^{88}$ Of the 3 known hypoxia-inducible transcription factors (HIFs), HIF-1 $\alpha$ is the best characterized. Here we review hypoxia and its role in the aggres-

\footnotetext{
Abbreviations used in this paper: $\alpha-\mathrm{KG}=\alpha$-ketoglutarate; $\mathrm{CA}-\mathrm{IX}$ $=$ carbonic anhydrase-IX; c-Met $=\mathrm{c}-$ mesenchymal-epithelial transition; DCA = dichloroacetate; EGFR = epidermal growth factor receptor; FIH-1 = factor inhibiting HIF-1; GBM = glioblastoma multiforme; GLUT-1 = glucose transporter $1 ; \mathrm{HIF}=$ hypoxia-inducible factor; HKII = hexokinase II; HRE = hypoxia response element; Hsp90 = heat shock protein $90 ; \mathrm{IDH}=$ isocitrate dehydrogenase; $\mathrm{LDH}=$ lactate dehydrogenase; $\mathrm{MSC}=$ mesenchymal stem cell; mTOR = mammalian target of rapamycin; PDK = pyruvate dehy drogenase kinase; PHD2 = prolyl hydroxylase domain 2; RACK1 = receptor for activated $\mathrm{C}$ kinase 1 ; shRNA = short hairpin RNA; siRNA = small interfering RNA; SUMO = small ubiquitin-like modifier; VEGF = vascular endothelial growth factor; VHL = von Hippel-Lindau.
}

sive phenotype of GBM, describe the normal physiology of HIF-1 $\alpha$, examine it as a therapeutic target in GBM, and review current knowledge regarding important molecules that regulate HIF- $1 \alpha$ and those it regulates in GBM pathophysiology. We also review HIFs as potential therapeutic targets in the treatment of this tumor.

\section{The Role of Hypoxia in GBM}

Many studies support the hypothesis that a hypoxic environment is crucial for tumor growth and development and is correlated inversely with patient survival. ${ }^{76,229}$ Furthermore, in some tumor types, hypoxia markers have been shown to be predictive of patient outcome. ${ }^{57,83}$ Thus, determining hypoxia levels may allow us to predict the extent of an aggressive phenotype. For instance, the characteristics of increased metastases, ${ }^{220}$ tumor recurrence, ${ }^{77}$ increased invasion, ${ }^{33,63}$ and resistance to chemotherapy ${ }^{59,196}$ and radiation ${ }^{59,189,239}$ have been extensively studied and implicated as hypoxia-mediated changes in solid tumors. These changes that potentially drive hypoxia-mediated malignant progression, including genomic instability, loss of apoptotic potential, oncogene expression, and abnormal angiogenesis have been described in GBM.$^{88}$ Furthermore, the presence of intratumoral necrosis is highly characterized in GBM, such that histological diagnosis of GBM depends on the presence of tumor necrosis and the cluster of cells that surround the necrotic area. ${ }^{88}$ Therefore, it is 
reasonable to hypothesize that hypoxia-mediated pathways could have a similar role and effect in this highly aggressive brain tumor. ${ }^{89}$

Chemotherapy is the standard of care for treating GBM ${ }^{156,216}$ but GBM routinely develops resistance to any given chemotherapy regimen. ${ }^{197}$ This response is hypothesized to be hypoxia related. ${ }^{26,150}$ In addition to chemotherapy, radiation therapy is often used in the treatment of GBM; ${ }^{123,214}$ however, just as hypoxia influences radiation resistance in vitro, this response is also observed in GBMs. ${ }^{10,46}$ Antiangiogenic therapy is a more recent option for treatment of patients with GBM. Because GBM is one of the most highly vascularized tumors, with substantial vascular proliferation and angiogenesis, ${ }^{47,186,192,224}$ therapy in the form of the anti-vascular endothelial growth factor (VEGF) antibody drug bevacizumab is typically considered in the treatment of patients with these tumors. Unfortunately, like chemo- and radiation therapy, antiangiogenic therapy is often plagued by the development of resistance as well. $8,22,37,172$ Therefore, because of the involvement of hypoxia in GBM development, targeting hypoxia-regulated proteins such as HIF-1, HIF-2, and HIF-3 and their associated regulators and targets in this highly resistant and aggressive brain tumor could result in significant benefits for cancer patients.

\section{The Normal Physiology of HIF-1}

The HIFs are all heterodimers composed of a major $\mathrm{O}_{2}$-sensitive subunit (HIF-1 $\alpha$, HIF-2 $\alpha$, or HIF-3 $\alpha$ ) and a constitutive HIF-1 $\beta$ subunit, which bind together in the nucleus to form the HIF-1, HIF-2, or HIF-3 transcriptional activation complexes. ${ }^{109} \mathrm{Of}$ these $3 \alpha$-subunits, HIF$1 \alpha$ and HIF-2 $\alpha$ are the best understood and seem to have both redundant and unique complementary functions. ${ }^{103}$ However, there are very few studies of HIF-2 in the context of GBM, although there is evidence that it is associated with poor patient outcome, is more active in chronic hypoxia, and plays a role in glioma stem cell maintenance, invasion, and tumorigenesis. ${ }^{52,109,129}$ Because HIF-1 is the best-characterized hypoxia-regulated molecule in GBM, we will limit our discussion to it for the purpose of this review.

HIF-1 is a member of the PAS (per/aryl-hydrocarbonreceptor nuclear translocator [ARNT]/Sim) family of basic helix-loop-helix transcription factors. It is composed of 2 subunits: HIF-1 $\alpha$, an $\mathrm{O}_{2}$-sensitive subunit; and HIF-1 $\beta$, a constitutively expressed subunit. ${ }^{67,233}$ Under normoxic conditions, the HIF-1 $\alpha$ protein is regulated by 2 independent mechanisms at the posttranscriptional level (Fig. 1). ${ }^{93}$ One mechanism is characterized by asparagine residue 803 becoming hydroxylated by factor inhibiting HIF-1 (FIH-1), an $\alpha$-ketoglutarate $(\alpha-\mathrm{KG})$-dependent dioxygenase with an $\mathrm{Fe}^{+2}$ catalytic center, which then inhibits interaction between HIF-1 and the nuclear coactivator CBP/ p300. ${ }^{15,74,140,204}$ The second mechanism involves hydroxylation of the proline residues Pro402 or Pro564, or both, by the prolyl hydroxylase domain 2 (PHD2), another protein with an $\mathrm{Fe}^{+2}$ catalytic center, and uses $\mathrm{O}_{2}$ and $\alpha-\mathrm{KG}$ as substrates and generates $\mathrm{CO}_{2}$ and succinate as byproducts. ${ }^{204}$ This hydroxylation leads to binding and $26 \mathrm{~S}$ proteasomal degradation of HIF-1 $\alpha$ by the elongin B- and elongin C-interacting von Hippel-Lindau (VHL) protein, the substrate recognition component of an E3 ubiquitin ligase.$^{203,204}$ Another regulatory protein, ARD1, has been shown to acetylate lysine residue 532 of HIF-1 $\alpha$ in mouse cells, appearing to promote ubiquitination of murine HIF1 in a VHL-dependent manner; ${ }^{90}$ however, because ARD1 does not have these properties in human cells, its function remains unclear. 9

Under hypoxic conditions $\left(1 \%-2 \% \mathrm{O}_{2}\right)$, both of the above-mentioned regulatory mechanisms of HIF- $1 \alpha$ become inhibited by substrate $\left(\mathrm{O}_{2}\right)$ deprivation. Furthermore, sumoylation of lysine residues 477 and 391 by the small ubiquitin-like modifier (SUMO)-1 enhances HIF-1 $\alpha$ stability and upregulation, further augmenting its transcriptional activity. ${ }^{6,205}$ These processes allow HIF- $1 \alpha$ to then dimerize with HIF-1 $\beta$, which then binds and activates DNA promoter regions called hypoxia response elements (HREs). These HREs help the cell cope with low $\mathrm{O}_{2}$ conditions by inducing the transcription of $>100$ genes, such as VEGF, erythropoietin, glucose transporter 1 (GLUT-1), carbonic anhydrase-IX (CA-IX), enolase, lactate dehydrogenase $(\mathrm{LDH})$, tyrosine hydroxylase, aldolase A, phosphoglycerate kinase (PGK), transferrin and its associated receptor, and certain growth factors (Fig. 1). ${ }^{88,89}$

\section{Involvement of HIF-1 in Oncogenesis}

The best-known tumor syndrome associated with HIF-1 is autosomal dominant VHL disease. VHL disease results from the loss of the tumor suppressor protein VHL encoded on chromosome 3p. ${ }^{98}$ As shown in Fig. 1, VHL plays a pivotal role in the hypoxia-regulated control of HIF-1. Thus, a loss of VHL results in HIF-1 accumulation and subsequent upregulation of all HIF-1-controlled proteins. ${ }^{113,167,190,253}$ VHL syndrome is characterized by tumors with high vascularity, such as hemangioblastomas, endolymphatic sac tumors, renal cell carcinoma, and pheochromocytomas. ${ }^{88}$ This highly vascular phenotype is thought to be the result of VEGF-mediated angiogenesis, secondary to loss of HIF-1 control via a loss of VHL. This is further supported by studies demonstrating that restoring wild-type VHL restores $\mathrm{O}_{2}$-dependent expression of HIF- $1 \alpha$ and HIF-1-mediated transcriptional activity. ${ }^{111,146}$

Further studies demonstrate that in $\mathrm{VHL}^{-/}$renal cell carcinoma cells, restoring VHL function is sufficient to decrease these cells' ability to form tumors in nude mice. ${ }^{24,62}$ In some neurological tumors such as hemangioblastomas and endolymphatic sac tumors, the VHL/HIF-1 pathway is important for pathogenesis and tumorigenesis; however, with regard to the highly aggressive GBM, few studies have shown the VHL/HIF-1 system to be a model for tumorigenesis. Recently, VHL has been found to regulate the signal transducer and activator of transcription 3 (STAT3), which in turn increases the tumorigenicity and "stemness" of U87 cells grown as neurospheres in vitro and in a mouse flank model..$^{101}$ VHL has also been implicated in regulation of the microRNA-23b, which is upregulated in GBM, and reduces the expression of VHL, while also being repressed by VHL in a negative feedback loop. ${ }^{25}$ Thus, overexpression of microRNA-23b in GBM reduces VHL activity and increases HIF-1 protein levels. 


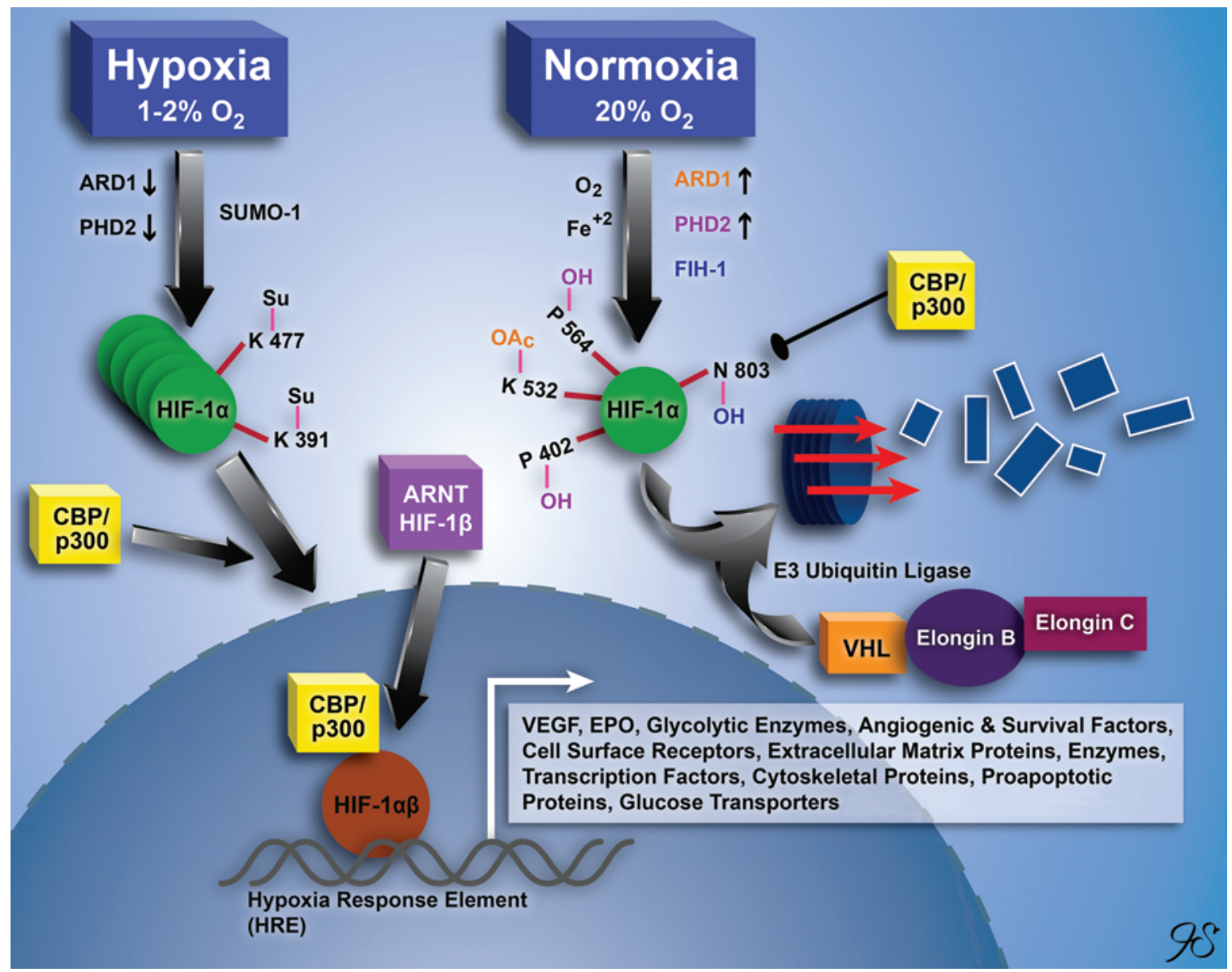

FIG. 1. Schematic representation of hypoxic control of HIF-1 $\alpha$ regulation and downstream HIF-1 $\alpha$ activity. The HIF-1 is composed of 2 heterodimeric subunits, HIF-1 $\alpha$ and HIF-1 $\beta$, which are constitutively expressed. Under normoxic conditions, the $\mathrm{HIF}-1 \alpha$ protein is regulated by 2 independent mechanisms at the posttranscriptional level. One mechanism is characterized by asparagine residue 803 becoming hydroxylated by $\mathrm{FIH}-1$, an $\alpha-\mathrm{KG}$-dependent dioxygenase with an $\mathrm{Fe}^{+2}$ catalytic center, which then inhibits interaction between HIF-1 and the nuclear coactivators CBP/p300. The second mechanism involves hydroxylation of the proline residues Pro402 or Pro564, or both, by the PHD2-another protein with an Fe+2 catalytic center-and uses $\mathrm{O}_{2}$ and $\alpha-K G$ as substrates and generates $\mathrm{CO}_{2}$ and succinate as byproducts. This hydroxylation leads to binding and $26 \mathrm{~S}$ proteasomal degradation of HIF-1 $\alpha$ by the elongin B-and elongin C-interacting VHL, the substrate recognition component of an E3 ubiquitin ligase. Under hypoxic conditions $\left(1 \%-2 \% \mathrm{O}_{2}\right)$, both of these regulatory mechanisms of HIF-1 $\alpha$ become inhibited by substrate $\left(\mathrm{O}_{2}\right)$ deprivation. Furthermore, sumoylation of lysine residues 477 and 391 by SUMO-1 enhances HIF-1 $\alpha$ stability and upregulation, further augmenting its transcriptional activity. These processes allow HIF-1 $\alpha$ to dimerize with HIF-1 $\beta$, which then binds and activates DNA promoter regions called HREs. These HREs help the cell cope with low $\mathrm{O}_{2}$ conditions by inducing the transcription of $>100$ genes involved in various cellular survival pathways, including those involved in glucose uptake, glycolysis, and angiogenesis. (Figure reproduced with permission of the Department of Neurosurgery, University of Utah.)

Some investigators have found that the role of HIF1 in tumor formation may not be so straightforward. In some instances, HIF-1 has been shown to function as a tumor suppressor in embryonic stem cells, ${ }^{21,138}$ human astrocytes, ${ }^{110}$ brain tumor, ${ }^{11}$ and breast ${ }^{28}$ and leukemic cells. ${ }^{210}$ This phenomenon is most apparent when cells are grown in vivo. To further complicate matters, one of these studies found that transformed murine $\Delta \mathrm{HIF}-1 \alpha$ astrocytes had poor tumor growth in a vascular-poor mouse flank model, but were very aggressive when implanted orthotopically. ${ }^{11}$ Another found that MDA-MB-231 breast cancer cells overexpressing HIF-1 $\alpha$ form significantly smaller tumors than wild-type cells in vivo; however, when those same cells are coinjected with fibroblasts overexpressing HIF$1 \alpha$ (which by themselves do not form tumors), a substan- tial increase in tumorigenesis and metastasis is observed. ${ }^{28}$ It should be noted that in both of these studies HIF-1 $\alpha$ was either completely removed or constitutively expressed in cells prior to implantation. In our own investigations, we have noted that U251 cells with constitutive HIF-1 $\alpha$ short hairpin RNA (shRNA) knockdown are more aggressive orthotopically (unpublished data, 2006) than wild-type U251 cells that are allowed to form tumors prior to silencing HIF-1 $\alpha$ through small interfering RNA (siRNA) injections, which subsequently reduces tumor growth significantly. ${ }^{60}$ This indicates that the timing of HIF-1 activity knockout during tumor growth is an important factor and can cause widely varied results. It also highlights the complicated nature of HIF-1's role in tumor development and the intricate web of intra- and extracellular pathways 
involved. Future research must be carefully designed to address these questions of microenvironmental effects.

\section{Involvement of HIF-1 in GBM}

The role of HIF-1 in pathogenesis has been studied in many tumor types, such as prostate cancer ${ }^{29}$ squamous cell carcinoma, ${ }^{125}$ lung cancer, ${ }^{234}$ breast cancer, ${ }^{254}$ bladder cancer ${ }^{223}$ pancreatic cancer ${ }^{70}$ and many other non-CNS tumors. ${ }^{88}$ This also includes brain tumors, which have been shown to correlate with HIF-1 $\alpha$ protein levels, tumor grade, and vascularity. ${ }^{49,248}$ Therefore, it is not surprising that glioma cell lines in vitro and in vivo overexpress HIF$1 \alpha$, in both normoxic and hypoxic conditions. . $^{5,89,102,108}$ Because of this, directly targeting HIF-1 is a reasonable approach for treatment of GBM.

It has been demonstrated that hypoxia in GBM causes an increase in proangiogenic factors, such as VEGF and stromal-derived factor-1, and recruitment of bone marrow-derived cells, such as vascular progenitor cells, stromal cells, mesenchymal stem cells (MSCs), and monocytes that have the capacity to stimulate endothelial cell recruitment and new blood vessel growth.,5,50 This is enforced by data in GBM showing that HIF-1 promotes angiogenesis and tumor growth through the recruitment of various proangiogenic bone marrow-derived CD45+ myeloid cells, F4/80+ tumor-associated macrophages, and endothelial and pericyte progenitor cells. ${ }^{3,39}$ The recruitment of MSCs by GBM is so pronounced that it has been proposed as a possible delivery route for targeted therapies, such as IFN- $\beta$, which has been shown to increase survival significantly in a U87 orthotopic mouse model when delivered via genetically engineered human MSCs that localized specifically to the tumor in vivo. ${ }^{159}$

Recruitment, pseudopalisading necrosis, and the abnormal vascular development that results from chaotic angiogenesis are some classic histological markers of GBM. ${ }^{14}$ Hypoxia in these pseudopalisading cells surrounding micronecrotic areas encourages infiltration by inflammatory cells, which can further stimulate the normoxic activation of HIF-1. ${ }^{100,192,206}$ Localized inflammation is an important contributing factor in the development of GBM, as demonstrated by the presence of infiltrating immune cells and the expression of inflammatory cytokines. ${ }^{225}$ Because HIF-1 is connected with prominent proinflammatory mediators such as interleukin (IL)-1 $\beta$ and nuclear factor $(\mathrm{NF})-\kappa \mathrm{B}$, it is a central player in linking inflammation and tumorigenesis in GBM. ${ }^{206}$ The $I L-1 \beta$ gene is a target for HIF-1 activation and is a proinflammatory cytokine with pluripotent activity, including the promotion of angiogenesis, tumor growth, and metastasis. ${ }^{249}$ This link suggests a mechanism for inflammation stimulating HIF-1 activity in the normoxic areas of tumors, particularly in the mesenchymal subtypes of GBM, which show activated Ras and immune cell infiltrates. ${ }^{206}$

\section{Targeting of HIF-1 as a Treatment for GBM}

Several studies have demonstrated that molecular targeting of HIF-1 $\alpha$ that results in decreased HIF-1 $\alpha$ protein levels is a potential therapeutic approach for GBM. For ex- ample, when the malignant glioma cell line U251, which has elevated VEGF and HIF-1 expression, is transfected with a dominant-negative HIF-1 $\alpha$ expression vector, the HIF-1 $\alpha$ activity and thus VEGF secretion decrease, resulting in growth inhibition. ${ }^{89}$ Similarly, knockdown of HIF$1 \alpha$ by siRNA results in decreased glioma growth both in vitro and in vivo, and increased survival when used in a continuous delivery system in mice, ${ }^{53,61}$ as well as decreased glioma cell migration and invasiveness in vitro under hypoxia. ${ }^{54}$ Furthermore, data show that by transfecting glioma cells with a constitutive HIF- $1 \alpha$ shRNA expression plasmid to inhibit the expression of HIF-1 $\alpha$, the cells become more sensitive than controls to the chemotherapeutic drugs doxorubicin and etoposide. ${ }^{26}$ In addition, the role of HIF-1 in radioresistance has been well documented in many different tumor types, including GBM. ${ }^{69,72,149}$ This role has been verified by in vitro and in vivo studies showing that blockade of HIF-1 activity through different mechanisms results in radiosensitivity. ${ }^{64,71,104}$ This pivotal role of HIF-1 $\alpha$ in promoting both chemo- and radioresistance in tumors indicates that targeting it will improve the outcome of treatment if used as a combined therapy.

In recently approved or currently active Phase II trials, HIF-1 $\alpha$ inhibitors have been shown to decrease its expression through several mechanisms in different tumors (Table 1). In addition, the HIF-1 $\alpha$ inhibitors PX-478 and YC-1 ${ }^{149}$ show promising results for advanced solid tumor treatment, recently having finished a Phase I clinical trial. ${ }^{122}$ Furthermore, several preclinical research projects developing HIF-1 $\alpha$ inhibitors are underway. ${ }^{169}$

In glioma, studies have demonstrated that the HIF$1 \alpha$ inhibitors $103 \mathrm{D} 5 \mathrm{R},{ }^{222}$ zinc, ${ }^{160}$ grape seed extract, ${ }^{133}$ and KC7F2 ${ }^{161}$ decrease HIF-1 $\alpha$ expression. A few specific small-molecule inhibitors of HIF-1 have recently shown progress as potential therapeutic strategies for GBM. Decreased GBM cell invasion under hypoxic conditions occurs through inhibition of HIF- $1 \alpha$ and its major transregulating factors by the cyclin-dependent kinase 2,7,9 selective inhibitor SNS-032. ${ }^{4}$ Under normoxia and hypoxic conditions, melatonin exerts antimigratory and antiinvasive effects in GBM cells by blocking HIF-1 $\alpha$ protein expression. Also, under hypoxic conditions in which GBM cells are found to produce reactive oxygen species (ROS), melatonin destabilizes HIF- $1 \alpha$ protein via its antioxidant activity against the ROS. ${ }^{250}$

The chemotherapy drug temozolomide has been a frontline therapy for patients with GBM tumors. ${ }^{215}$ Unfortunately, because GBM often becomes resistant to most chemotherapy agents, ${ }^{197}$ the same holds true for temozolomide; ${ }^{75}$ however, noscapine, a small-molecule inhibitor of HIF- $1 \alpha$ that induces apoptosis in human glioma cells, ${ }^{163}$ may serve as a therapeutic alternative in the treatment of temozolomide-resistant GBM. ${ }^{92}$ Noscapine has also been shown to synergistically potentiate the effects of temozolomide as well as other chemotherapeutic agents ${ }^{181}$ in the treatment of GBM. Furthermore, conjugating polyethylene glycol solid lipid nanoparticles to noscapine improves its biological half-life, brain delivery, and efficacy in GBM cells, offering a possible approach to regulating the administration of multiple injections of noscapineyet this warrants further in vivo study. ${ }^{139}$ 
The HIF-1-associated proteins in glioblastoma

TABLE 1: Summary of HIF-1 inhibitors in Phase II trial or approved as of $2012^{*}$

\begin{tabular}{llll}
\hline \multicolumn{1}{c}{ Drug } & Status & \multicolumn{1}{c}{ Mechanism of HIF-1 Inhibition } & \multicolumn{1}{c}{ Reference(s) } \\
\hline CCL-779 & approved & HIF-1 $\alpha$ translation & $38,141,230$ \\
Camptothecins (CPTs) & approved & HIF-1 $\alpha$ translation & $182,183,227$ \\
2-Methoxyestradiol (2ME2) \& analogs & approved & HIF-1 $\alpha$ translation & 119,136 \\
Geldanamycin (GA) \& analogs & Phase II & HIF-1 $\alpha$ degradation & $84,137,177$ \\
SCH66336 & Phase II & HIF-1 $\alpha$ degradation & 68 \\
Apigenin & Phase II & HIF-1 $\alpha$ degradation & 48,170 \\
FK228 & approved & HIF-1 $\alpha$ degradation & 153 \\
PX-12 & Phase II & HIF-1 $\alpha$ degradation/transcriptional activity & 237 \\
Bortezomib & approved & transcriptional activity & 99 \\
Amphotericin B & approved & transcriptional activity & 246 \\
\hline
\end{tabular}

* Modified with permission from Xia et al.: Recent advances in hypoxia-inducible factor (HIF)-1 inhibitors. Eur J Med Chem 2012; 49:24-40. Copyright (C) 2012 Elsevier Masson SAS. All rights reserved.

\section{Upstream Targets of HIF-1 for GBM Therapy}

There are many molecules and pathways upstream of HIF-1 (Fig. 2), such as Ras, ${ }_{12}^{12}$ PI3K/Akt, ${ }^{23,30,176}$ PTEN, ${ }^{18,112,256}$ mammalian target of rapamycin (mTOR), ${ }^{195}$ and STAT3, ${ }^{135}$ that regulate its activity, provide opportunities for dysregulation and tumorigenesis, and have potential as therapeutic targets in GBM. Recently, developments have focused on the FIH-1, PHD2, SUMO, the transcriptional cofactor $\mathrm{CBP} / \mathrm{p} 300$, heat shock protein 90 (Hsp90), receptor for activated C kinase 1 (RACK1), and isocitrate dehydrogenase 1 (IDH-1) in GBM pathogenesis and for potential targeted therapy. Because these upstream regulators intimately interact with HIF-1 $\alpha$, we chose to expand on them for the purposes of this review.

\section{Factor Inhibiting HIF-1}

The FIH-1 is involved in blocking the transcriptional activity of HIF-1 under normoxic conditions via hydroxylation of an asparagine residue. ${ }^{204}$ Dysregulation of FIH-1 proves important in the tumorigenesis of GBM, supported by the fact that the $F I H-1$ gene, which is located at chromosome 10q24, is often deleted in GBM tumors. $55,81,127,211$ Furthermore, compared with normal brain tissues, GBM has a significant reduction of FIH-1 mRNA levels. ${ }^{188}$ Further examination of the role of FIH-1 in the pathogenesis of GBM found that even under hypoxic conditions, FIH-1 can inhibit HIF-1-mediated transcription of GLUT1 and VEGF-A in human GBM cells. ${ }^{231}$ This suggests that FIH1 has potential as a therapeutic target in treating GBM patients with poor prognosis.

\section{Prolyl Hydroxylase Domain 2}

The PHD2 protein is an important regulator in the $\mathrm{O}_{2}$ dependent degradation pathway of HIF-1 $\alpha$, a mechanism that can become inhibited under hypoxic conditions. ${ }^{204} \mathrm{In}$ GBMs, PHD2 can be induced by hypoxia in vitro and is expressed in hypoxic areas of tumors in vivo. Thus, it most likely remains operative to an extent at low $\mathrm{O}_{2}$ concentration, and therefore acts as a negative feedback loop to limit the hypoxic HIF-1 response, protecting GBM tumor cells from hypoxia-induced cell death. ${ }^{73}$ To the contrary, PHD2 has been further studied for its ability to enhance hypoxia-induced GBM cell death by modulation of $H I F$ 1 target gene expression of GLUT-1, VEGF-A, and bcl-2 binding protein 3.219 Taken together, these data suggest the need for further exploration of the PHD2/HIF-1 pathway, its pathogenesis in GBM, and its use as a novel therapeutic target in the treatment of GBM.

\section{Small Ubiquitin-Like Modifier 1}

The SUMO-1 protein conjugates to lysine residues, specifically to lysine residues 477 and 391, during HIF-1 $\alpha$ pathogenesis under hypoxic conditions, thus modifying HIF-1 activity, stability, and subcellular localization. ${ }^{6,205}$ Yang et al. ${ }^{245}$ showed that SUMO-1-conjugated proteins were significantly elevated in GBM tumor samples. Furthermore, silencing SUMO-1 expression and thus blocking conjugation in GBM cells blocked cell growth, DNA synthesis, and cell survival. It also resulted in cell cycle arrest and enzymatic indication of DNA damage, prompting further research to determine whether SUMO-1 could be a viable GBM therapeutic target upstream of HIF- $1 .{ }^{245}$

\section{$C B P / p 300$}

The $\mathrm{CBP} / \mathrm{p} 300$ proteins are nuclear coactivators that bind to and enable HIF-1 $\alpha$ transcription in the cell nucleus under hypoxic conditions. Thus, it would seem reasonable to target and prevent this molecular interaction between HIF-1 $\alpha$ and CBP/p300 as a potential therapeutic treatment. In fact, studies have effectively demonstrated inhibitors of this interaction in different cancers. ${ }^{16,158,187,207}$ In several glioma cell lines, the inhibitor arylsulfonamide interfered with HIF-1 signaling and disrupted HIF-1 $\alpha$ interaction with the nuclear cofactors $\mathrm{CBP} / \mathrm{p} 300$, inhibiting in vivo glioma growth, ${ }^{247}$ further suggesting the potential of the HIF- $1 \alpha / \mathrm{CBP} / \mathrm{p} 300$ interaction as a therapeutic target in GBM.

\section{Heat Shock Protein 90/Receptor for Activated C Kinase 1}

Although much attention is directed at the $\mathrm{O}_{2}$-dependent regulation of HIF-1, the half-life of HIF-1 is also 


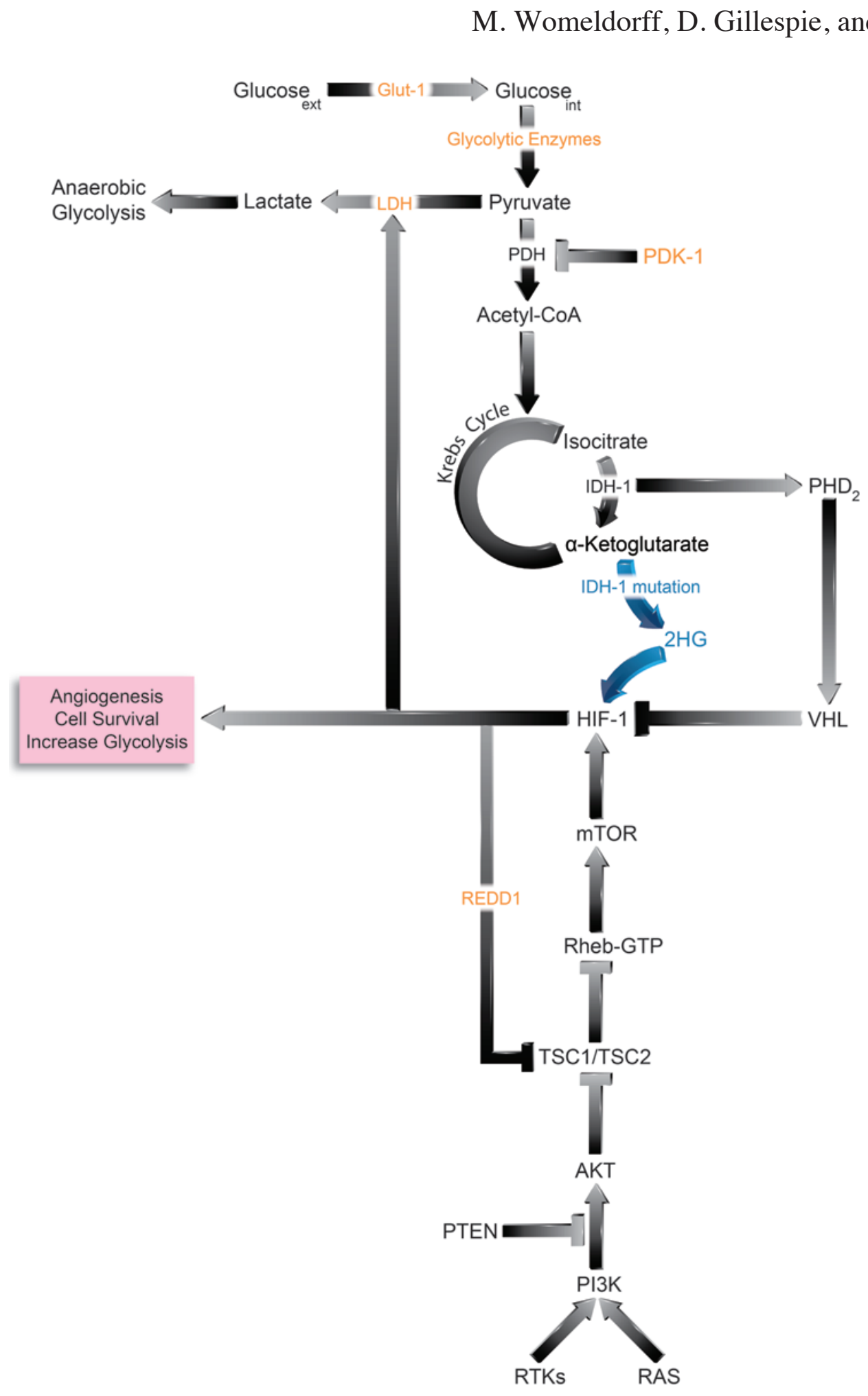

FIG. 2. Schematic representation of nonhypoxic and metabolic upstream regulation of HIF-1 $\alpha$. Translation of HIF-1 $\alpha$ mRNA into protein is dependent on the activity of the MTOR, which in turn is regulated by the activity of upstream tumor suppressor proteins including phosphatase and tensin homolog (PTEN) and tuberous sclerosis proteins TSC-1 (hamartin) and TSC-2 (tuberin), which are part of the receptor tyrosine kinase (RTK), GTPase protein Ras, GTP-binding protein Ras homolog enriched in brain (Rheb), serine/threonine-specific protein kinase (Akt), and phosphoinositide 3-kinase (PI3K) pathway. The protein regulated in development and DNA damage responses 1 (REDD1) is regulated by HIF-1 $\alpha$ and inhibits the tumor suppressor TSC1/TSC2, which in turn upregulates HIF-1 $\alpha$ translation. Proteins shown in orange are regulated directly by HIF-1 $\alpha$ and play a role in the cellular uptake of glucose (via GLUT-1), glycolytic enzymes, and the shift to anaerobic glycolysis (Warburg effect). Interestingly, mutations of IDH-1, commonly found in gliomas, alter the conversion of isocitrate to $\alpha-K G$, with a resultant oncometabolite 2-hydroxyglutarate (2-HG), which has a stabilizing effect on HIF-1 $\alpha$. PDH = pyruvate dehydrogenase. (Figure reproduced with permission of the Department of Neurosurgery, University of Utah.) 
regulated in an $\mathrm{O}_{2}$-independent manner. Either $\mathrm{Hsp} 90$ competitively binds HIF-1 and stabilizes the protein, or $\mathrm{RACK} 1$, an anchoring protein that interacts with elongin $\mathrm{C}$, competitively binds HIF-1 and thus promotes, independently of PHD2 and VHL, HIF-1 ubiquitination and degradation. ${ }^{131,204}$

Several groups have studied Hsp90 involvement in GBM and have proposed that its inhibition is a possible therapeutic measure for direct reduction of glioma tumor growth. ${ }^{58,154,252,255}$ Furthermore, current research has focused on the ability of Hsp90 knockdown or inhibition to attenuate the effects of radiation ${ }^{155,228}$ and drug therapy ${ }^{13}$ through increased cell sensitization, potentially offering a combinatorial and aggressive approach to GBM treatment by using Hsp90 targeting.

The RACK1 protein has been shown to be a potent molecular enhancer of tumorigenesis in several types of cancers, making it a potentially viable target for suppressing tumor growth, tumor cell proliferation, and tumor-associated angiogenesis..$^{20,78,126,232}$ With regard to malignant glioma, Peng et al. ${ }^{171}$ showed that RACK1 expression is significantly higher in glioma cell lines and tissues than in normal brain tissues and is associated positively with glioma malignancy. Furthermore, the proliferation and invasion of human glioma cell lines was suppressed by RACK1 downregulation via siRNA, whereas apoptosis of these cells became favored. Moreover, tumor xenograft growth in nude mice became inhibited with forced downregulation of RACK1. Given these effects in vitro and in vivo, it stands to reason that targeting RACK1 in GBM treatment may be an attractive approach.

\section{Isocitrate Dehydrogenase 1}

IDH-1 is a key enzyme in the citric acid cycle, converting isocitrate to $\alpha-K G$. Mutations in this protein occur in $>80 \%$ of WHO Grade II-III and secondary GBMs, but are almost nonexistent $(<5 \%)$ in primary tumors. ${ }^{166}$ This association is so consistent that IDH-1 mutations have been proposed as a diagnostic molecular marker of secondary GBMs, and it points to differing cells of origin between primary and secondary GBM. ${ }^{165}$ The most common of these mutations results in an amino acid substitution at arginine residue $132(\mathrm{R} 132 \mathrm{H})$. Using the NADPH-dependent reduction of $\alpha-\mathrm{KG}$, mutant IDH-1 (R132H) produces the 2-hydroxyglutarate metabolite. This metabolite influences several $\alpha-K G-$ dependent dioxygenase enzymes, including the HIF-1 $\alpha$ regulator PHD2, ${ }^{193}$ by acting as a competitive inhibitor (Fig. 2) ${ }^{193}$ Studies implicate ML309, a mutant IDH-1 (R132H) inhibitor, ${ }^{34,35}$ as well as glutaminase $^{201}$ in IDH-1 (R132H) mutant GBM cells as potential therapeutic approaches; however, positive IDH-1 mutation status correlates with a better prognosis in patients with GBM, which indicates that perturbing the wild-type IDH-1 pathway in primary GBM could improve patient outcome. ${ }^{174,213}$ Downregulation of LDHA and underexpression of other essential glycolysis genes may occur in IDH-1 mutant gliomas, contributing to the slow growth and better prognosis in these GBM tumor types. ${ }^{27}$ This research prompts further investigation into IDH-1, as well as LDHA, and their roles in GBM pathogenesis.

\section{Downstream Targets of HIF-1 for GBM Therapy}

During hypoxia, HIF-1 $\alpha$ binds to DNA HREs and induces transcription of many well-characterized genes, ${ }^{233}$ including almost every gene in the glycolytic pathway. ${ }^{51}$ Recent studies further implicate a link between aerobic glycolysis, HIF-1, and GBM tumorigenesis. Targeting individual parts of the glycolytic pathway such as LDHA ${ }^{121}$ may prove promising in cancer therapy, and knockdown of LDHA in glioma cells by siRNA or the inhibitor sodium oxamate has been shown to decrease those cells' migratory potential. ${ }^{200}$ The glycolytic enzymes pyruvate dehydrogenase kinase (PDK) and hexokinase II (HKII) are significant markers in the pathogenesis and targeted treatment of GBM. Furthermore, similar to the glycolytic enzymes CA-IX and GLUT-1, other hypoxia-regulated proteins transcribed by HIF- $1 \alpha$, such as the receptor tyrosine kinase c-Met and VEGF, 15,106,117,203 are overexpressed in malignant brain tumors. ${ }^{88,209,248}$

\section{The Warburg Effect}

Glucose metabolism via glycolysis is an essential component to GBM tumorigenesis, as evidenced by the observed apoptosis and cell death on withdrawal of glucose from GBM cells. ${ }^{87}$ Thus, modifying cellular metabolism by increasing glycolytic enzymes and therefore the glycolysis rate in tumor cells is desirable. This process is facilitated by activation of HIF-1 $\alpha$. Aerobic glycolysis is the adaptation of cancer cells through increased glycolysis in the presence of normal blood $\mathrm{O}_{2}$ tension. Also known as the Warburg effect, ${ }^{235}$ it is a necessary step toward an aggressive phenotype. ${ }^{208}$ A possible link between HIF1 and this effect in various types of cells ${ }^{191,244}$ has been proposed, prompting the hypothesis that dysregulation of HIF- $1 \alpha$ could increase aerobic glycolysis. ${ }^{132}$ There is also evidence that some products of dysfunctional aerobic glycolysis can stabilize HIF-1. For example, one study found that fumarate appears to be a proto-oncometabolite that functions by binding to glutathione, resulting in the stabilization of HIF-1 $\alpha ; ;^{218}$ however, a different group has proposed that fumarate inhibits PHD activity directly. ${ }^{175}$

Another product, succinate, which accumulates as a result of succinate dehydrogenase inhibition, reduces PHD activity, leading to HIF-1 $\alpha$ stabilization and activation. ${ }^{199}$ It is interesting to note that mutations in succinate dehydrogenase are linked to developing renal cell carcinoma, pheochromocytoma, and paraganglioma, all of which are also predominant in VHL disease, as discussed earlier. Furthermore, a complex of the HIF-1 upstream regulator mTOR has been implicated in promoting the Warburg effect in GBM cells. ${ }^{144,145}$ Therefore, increased attention is being given to targeting aerobic glycolysis as a potential route for GBM therapy. One study has shown that reversing the Warburg effect by using methylene blue decreases GBM cell proliferation in vitro. ${ }^{178}$ Furthermore, targeting the key metabolic enzymes in glycolysis, some of which we elaborate on below, is a potentially attractive option for GBM therapy. ${ }^{240}$

\section{Pyruvate Dehydrogenase Kinase}

In metabolic oncology, decreased glucose oxidation 
in the mitochondria and increased glycolysis provides a proliferative advantage, increased angiogenesis, and resistance to apoptosis in cancer cells. This shift in metabolism is largely mediated by the mitochondrial enzyme PDK. When PDK is activated, it selectively inhibits pyruvate dehydrogenase, a group of enzymes that catalyzes the oxidative decarboxylation of cytosolic pyruvate to mitochondrial acetyl-CoA, the substrate for the Krebs cycle, promoting increased cytosolic glycolysis and lactate production. ${ }^{221}$ Thus, it is reasonable to hypothesize that inhibition of PDK could modulate this shift in glycolytic metabolism and increase prognostic factors, thereby acting as a potential and attractive therapeutic target in patients with malignant gliomas. ${ }^{91}$

Combined targeting of PDK and epidermal growth factor receptor (EGFR) reverses the Warburg effect and triggers regression of GBM. ${ }^{226}$ Much research has focused on selective inhibition of PDK and modulation of glycolytic metabolism as a therapeutic target for GBM using the inhibitor dichloroacetate (DCA), ${ }^{152}$ demonstrating that it is a viable therapeutic agent in the treatment of glioma. ${ }^{40}$ Recently, a study showed that DCA decreases glycolytic metabolism via PDK metabolism in rat glioma cancer stem cells but not in rat neural stem cells, promising further therapeutic application in glioma. ${ }^{157}$ Another study showed that DCA radiosensitized several cancer cell lines in vitro, including LN18 glioma. ${ }^{257}$ Combining DCA with bevacizumab has been shown to overcome hypoxia-induced anti-VEGF resistance in vivo and has potential as a combinatorial anticancer strategy in GBM..$^{14}$ Currently, DCA is undergoing a Phase I clinical trial to continue investigation into its efficacy in patients with GBM and other recurrent brain tumors. ${ }^{202}$

\section{Hexokinase II}

Hexokinase II is an enzyme that phosphorylates glucose to create glucose- 6 phosphate for the initial step of glycolysis. In GBM, HKII is a key mediator of the Warburg effect, enabling aerobic glycolytic metabolism. As a result, HKII expression is elevated in GBM compared with normal brain and correlates with a poorer overall survival of patients with GBM; this finding is further supported by exogenous expression of HKII in GBM cells, which leads to therapeutic resistance, increased proliferation, and intracranial growth. ${ }^{241,242}$ Wolf and colleagues showed that mitochondrial oxidative metabolism of glucose was restored in GBM cells after depletion of HKII. This depletion also increased GBM cell sensitivity to radiation and temozolomide. Furthermore, intracranial xenograft GBM cells that are depleted of HKII exhibited decreased expression of VEGF and HIF-1 $\alpha$, as well as diminished angiogenesis and proliferation, but increased invasion. ${ }^{241}$ In another study, Wolf et al. ${ }^{242}$ demonstrated that partial epigenetic regulation for preferential expression of HKII occurs in aerobic glycolysis-dependent proliferative states such as the developing embryo and malignant human glioma tissue. ${ }^{242}$

A few inhibitors that target HKII in GBM pathogenesis have been examined. In U87MG cells, clotrimazole induced translocation of HKII from the mitochondria to the cytoplasm, which was followed by release of cytochrome c, suggesting a mechanism for apoptosis in these cells. Furthermore, treatment of these cells with clotrimazole sensitized them to radiation in vitro. ${ }^{130}$ Several recent studies support 3-bromopyruvate as a potentially efficacious and synergistic HKII inhibitor with anticancer activity in GBM, ${ }^{42-44}$ including a safe method for intracranial delivery in an animal model of glioma. ${ }^{238}$ Furthermore, tumorsuppressing microRNA-143 overexpression, which can be induced by the drug rapamycin, ${ }^{124}$ directly targets HKII to inhibit glycolysis in GBM. ${ }^{251}$ Taken together, these studies suggest that targeted treatment of HKII may be viable in GBM therapy.

\section{Carbonic Anhydrase-IX}

In patients with GBM, hypoxia-inducible overexpression of CA-IX occurs, but its functions in this context remain elusive. ${ }^{180}$ In the U251 and LN18 glioblastoma cell lines, the malignant phenotypes of cell attachment and invasion seem correlated with CA-IX expression, because RNA interference to CA-IX strongly reduces these characteristics. ${ }^{180}$ It has been hypothesized that overexpression of CA-IX under hypoxic conditions may maintain an acidic extracellular $\mathrm{pH}$, a fundamental property of the malignant phenotype, through enzyme-mediated conversion of $\mathrm{CO}_{2}$ to a proton, which is extruded in the extracellular environment, and to a bicarbonate ion that is transported to the cytoplasm. ${ }^{85,180}$ Also, because high CA-IX expression is identified as an independent factor for poor survival in patients with GBM, targeted therapy for CA-IX is highly desirable..$^{180}$

In cancer, CA-IX expression seems to correlate with poor response to adjuvant treatment. ${ }^{179,212}$ In malignant gliomas, CA-IX expression also predicts survival and radiographic response of patients treated with the chemotherapy drugs bevacizumab and irinotecan. ${ }^{198} \mathrm{~A}$ recent study showed that inhibition of CA-IX enhanced the effect of anti-VEGF therapy with the drug bevacizumab, exhibiting a greater reduction in the growth rate of a U87 GBM cell line xenograft tumor than inhibition of CA-IX or bevacizumab treatment alone. ${ }^{148}$ Furthermore, after CA-IX knockdown and RNA-mediated interference, the effects of chemotherapy and radiation were strongly enhanced and accompanied by an increased rate of cell death by apoptosis in U251 and LN18 cell lines. ${ }^{180}$ Inhibiting CA-IX enzymatic activity by applying a specific CA-IX inhibitor sulfonamide or molecular inhibition via siRNA led to inhibition of its functional role during GBM tumorigenesis. ${ }^{194}$ Thus, experimental data show that targeting this downstream enzyme of HIF-1 transcription as a therapeutic target in GBM shows potential. Although CA-IX is understood as a hypoxia-induced protein, under normoxic conditions CA-IX expression has been shown to be enhanced in GBM cells when an extracellular acidotic environment is present. ${ }^{82}$ These data suggest that further investigation into the relationship between $\mathrm{pH}$ metabolism and regulation, $\mathrm{O}_{2}$ concentration, and GBM expression profile and tumorigenesis may prove fruitful.

\section{Glucose Transporter 1}

GLUT-1 is a transmembrane glycoprotein that me- 
diates sodium ion-independent transport of glucose into cells. ${ }^{7}$ Because glucose is unable to cross the blood-brain barrier, glucose transport into the brain is mediated by GLUT family proteins, with the most commonly expressed isoform being GLUT-1. ${ }^{164}$ During hypoxia, GLUT1 becomes overexpressed via transcription by HIF- $1 \alpha .88,89$ Like CA-IX expression, GLUT-1 expression also correlates with poor response to adjuvant treatment, ${ }^{32}$ as well as a worse prognosis in patients with a wide variety of cancers. ${ }^{88,89}$ Therefore, therapeutic inhibitors of GLUT-1 seem to be a highly attractive approach to cancers that overexpress this gene, as evidenced by a study that shows that inhibition of glucose transporters in lung and breast cancer induces apoptosis. ${ }^{184}$ Furthermore, GLUT-1 inhibition in breast and colon cancer cell lines under hypoxia increases chemosensitivity with daunorubicin ${ }^{19}$ and vincristine ${ }^{142}$ for an erythroblastoma cell line. For brain tumor therapy, implicating GLUT-1 as a target for treatment may prove challenging, because high levels of this protein in the blood-brain barrier help maintain basal glucose levels in the brain, and this would be a major therapeutic problem to overcome. ${ }^{45}$ Furthermore, because of the overexpression of GLUT-1 transporters in GBM during hypoxia, efforts might be focused on developing therapeutic molecules that use the GLUT-1 system. For example, in the T98G GBM cell line, increased expression of GLUT-1 mRNA and protein increased the cytotoxic effects of glycoconjugated nitric oxide donors. ${ }^{217}$

\section{c-Mesenchymal-Epithelial Transition}

Immunohistochemical expression of c-mesenchymal-epithelial transition (c-Met) in GBM is an independent predictor of outcomes in patients with these tumors. ${ }^{168}$ Our group has recently demonstrated that inhibition of HIF-1 $\alpha$ directly inhibits c-Met. ${ }^{60}$ This protein is a receptor tyrosine kinase that promotes the stem cell phenotype of GBM when activated by HIF-1, ${ }^{36}$ by influencing the expression of reprogramming transcription factors, which support embryonic stem cells and induce pluripotent stem cell formation from differentiated cells. ${ }^{128}$ Furthermore, activation of c-Met influences cell invasiveness. ${ }^{31,41}$ Thus, targeted treatment of c-Met in GBM seems desirable, as supported by a study showing that when treated with cMet inhibitors, various lung cancer cell types lose their invasive phenotypes. ${ }^{120}$ In fact, inhibition of c-Met signaling in GBM stem cells disrupts tumor growth and invasiveness both in vivo and in vitro. ${ }^{95}$

Attempts at EGFR inhibition in GBM often induce high levels of c-Met activation as a mechanism of antiEGFR resistance, further potentiating c-Met as a therapeutic target. ${ }^{96}$ Inhibition of c-Met expression using chimeric transgenes decreases GBM tumor growth and malignancy, ${ }^{2}$ including decreased angiogenesis as well as increased apoptosis in vivo. ${ }^{1}$ Studies have also shown that therapeutic antibodies that disrupt the interaction between the ligand of the c-Met receptor, hepatocyte growth factor, and the receptor itself $17,107,143,151$ have a therapeutic effect. Other inhibitors, such as the orally bioavailable SGX523, inhibit glioma stem cell malignancy and intracranial tumor growth. ${ }^{65}$ Enhancing c-Met siRNA delivery via conjugation to cationic solid lipid nanoparticles decreased
GBM cell proliferation in vitro and decreased GBM tumor growth in vivo. ${ }^{94}$ Furthermore, targeting the c-Met pathway potentiates GBM cell response to radiation, ${ }^{118,236}$ and the c-Met antibody inhibitor AMG102 may also potentiate GBM cell radiosensitivity ${ }^{16}$ and increase effects of the chemotherapeutic drug reagents temozolomide and docetaxel, ${ }^{97}$ suggesting that combination therapy with c-Met inhibitors may be an attractive approach. As understanding of c-Met and its role in GBM pathogenesis develops, discovering therapies that target c-Met maintenance of the stem cell phenotype are desired, as demonstrated by one study showing that inhibition of c-Met reduces the propagation of glioma stem-like cells in vivo. ${ }^{185}$

\section{Vascular Endothelial Growth Factor}

Treatment in the form of anti-VEGF therapy with the antibody drug bevacizumab can be used for GBM, but unfortunately resistance often develops. ${ }^{8,22,37,172}$ Efforts to better understand mechanisms of resistance are currently underway. To improve the design of antiangiogenic treatment strategies, we need more details about tumor neovascularization, including VEGF-independent processes. ${ }^{115}$ Another study describes hypoxia-mediated autophagy as a promoter of GBM tumor cell survival and as a mechanism for antiangiogenic therapy resistance. Because antiangiogenic therapy leads to hypoxia, hypoxia-induced tumor cell autophagy was observed as an adaptive cytoprotective response. ${ }^{79}$ In GBM, downregulation of the $c y l$ indromatosis (CYLD) gene, a tumor suppressor that acts as a de-ubiquitinating enzyme to regulate signaling pathways, may be crucial for hypoxia-mediated inflammation, which is hypothesized to affect the long-term efficacy of anti-VEGF therapy. ${ }^{66}$ Furthermore, a proneural-to-mesenchymal transition as well as upregulation of genes associated with cellular migration, invasion, and inflammation facilitates resistance to anti-VEGF therapy. ${ }^{173}$ Taken together, these data suggest that continued elucidation of mechanisms of antiangiogenic therapy evasion by highgrade GBM is warranted for more effective treatment with this approach. ${ }^{134}$

A more invasive phenotype and expression of matrix metalloproteinase have been found in studies of bevacizumab-treated GBM. ${ }^{56,105}$ The receptor tyrosine kinase c-Met, which is also upregulated in response to therapy with bevacizumab, ${ }^{147}$ is hypothesized to mediate this phenotype transition and to have potential as a mediator of antiangiogenic therapy resistance in vivo. ${ }^{86}$ Therefore, dual targeting of c-Met and VEGF activity may prove to be an effective alternative to bevacizumab alone. In gliomas, bevacizumab-induced invasion has been shown to be inhibited by broad-spectrum kinase inhibitors. ${ }^{80}$ Another study cites the potential of cabozantinib, a dual inhibitor of c-Met and VEGFR2 tyrosine kinase with prominent inhibition in vitro, but in vivo studies suggested the need for improvement in delivery of the drug to the tumor and/or surrounding tissue for enhanced effectiveness. ${ }^{162}$ Because increased invasion proves to be a mechanism of antiVEGF resistance, further research is necessary to elucidate the role of c-Met in this process and the implications that this molecular relationship might have for therapy in patients with GBM. 


\section{Conclusions}

Although a diagnosis of GBM yields a poor prognosis for cancer patients, there are broad, intense research efforts directed at finding suitable therapies for the treatment of patients with this tumor. In tumorigenesis, hypoxia and, most notably, the hypoxia-induced molecule HIF-1 $\alpha$, play important roles. HIF-1 and its upstream and downstream molecules have been clearly implicated in GBM pathogenesis, suggesting that they are potential therapeutic targets for treatment of these tumors. Although in many instances additional research is warranted, it is clear that HIF-1 and its associated proteins are promising avenues for translational studies. Additional understanding of the role of HIF-1 and its molecular regulators and downstream targets in GBM pathophysiology, and which of those are viable therapeutic targets, may lead to better treatment outcomes and enhanced prognosis for patients with this devastating disease.

\section{Acknowledgments}

We thank Kristin Kraus, M.Sc., for editorial assistance and Jennie Williams, M.A., for preparing the illustrations.

\section{Disclosure}

Dr. Jensen is a consultant for Varian, Medtronic, and PharmacoKinesis.

Author contributions to the study and manuscript preparation include the following. Conception and design: all authors. Drafting the article: all authors. Critically revising the article: all authors. Reviewed submitted version of manuscript: all authors. Approved the final version of the manuscript on behalf of all authors: Jensen. Study supervision: Jensen.

\section{References}

1. Abounader R, Lal B, Luddy C, Koe G, Davidson B, Rosen EM, et al: In vivo targeting of SF/HGF and c-met expression via U1snRNA/ribozymes inhibits glioma growth and angiogenesis and promotes apoptosis. FASEB J 16:108-110, 2002

2. Abounader R, Ranganathan S, Lal B, Fielding K, Book A, Dietz $\mathrm{H}$, et al: Reversion of human glioblastoma malignancy by U1 small nuclear RNA/ribozyme targeting of scatter factor/ hepatocyte growth factor and c-met expression. J Natl Cancer Inst 91:1548-1556, 1999

3. Aghi M, Cohen KS, Klein RJ, Scadden DT, Chiocca EA: Tumor stromal-derived factor-1 recruits vascular progenitors to mitotic neovasculature, where microenvironment influences their differentiated phenotypes. Cancer Res 66:9054-9064, 2006

4. Ali MA, Reis A, Ding LH, Story MD, Habib AA, Chattopadhyay A, et al: SNS-032 prevents hypoxia-mediated glioblastoma cell invasion by inhibiting hypoxia inducible factor-1alpha expression. Int J Oncol 34:1051-1060, 2009

5. Annabi B, Lee YT, Turcotte S, Naud E, Desrosiers RR, Champagne M, et al: Hypoxia promotes murine bone-marrow-derived stromal cell migration and tube formation. Stem Cells 21:337-347, 2003

6. Bae SH, Jeong JW, Park JA, Kim SH, Bae MK, Choi SJ, et al: Sumoylation increases HIF-1alpha stability and its transcriptional activity. Biochem Biophys Res Commun 324:394400, 2004

7. Behrooz A, Ismail-Beigi F: Stimulation of glucose transport by hypoxia: signals and mechanisms. News Physiol Sci 14: 105-110, 1999
8. Bergers G, Hanahan D: Modes of resistance to anti-angiogenic therapy. Nat Rev Cancer 8:592-603, 2008

9. Bilton R, Mazure N, Trottier E, Hattab M, Déry MA, Richard DE, et al: Arrest-defective-1 protein, an acetyltransferase, does not alter stability of hypoxia-inducible factor (HIF)-1alpha and is not induced by hypoxia or HIF. J Biol Chem 280: 31132-31140, 2005

10. Bloom HJ: Intracranial tumors: response and resistance to therapeutic endeavors, 1970-1980. Int J Radiat Oncol Biol Phys 8:1083-1113, 1982

11. Blouw B, Song H, Tihan T, Bosze J, Ferrara N, Gerber HP, et al: The hypoxic response of tumors is dependent on their microenvironment. Cancer Cell 4:133-146, 2003

12. Blum R, Jacob-Hirsch J, Amariglio N, Rechavi G, Kloog Y: Ras inhibition in glioblastoma down-regulates hypoxia-inducible factor-1alpha, causing glycolysis shutdown and cell death. Cancer Res 65:999-1006, 2005

13. Boridy S, Le PU, Petrecca K, Maysinger D: Celastrol targets proteostasis and acts synergistically with a heat-shock protein 90 inhibitor to kill human glioblastoma cells. Cell Death Dis 5:e1216, 2014

14. Brat DJ, Castellano-Sanchez AA, Hunter SB, Pecot M, Cohen $\mathrm{C}$, Hammond $\mathrm{EH}$, et al: Pseudopalisades in glioblastoma are hypoxic, express extracellular matrix proteases, and are formed by an actively migrating cell population. Cancer Res 64:920-927, 2004

15. Brat DJ, Mapstone TB: Malignant glioma physiology: cellular response to hypoxia and its role in tumor progression. Ann Intern Med 138:659-668, 2003

16. Buchanan IM, Scott T, Tandle AT, Burgan WE, Burgess TL, Tofilon PJ, et al: Radiosensitization of glioma cells by modulation of Met signalling with the hepatocyte growth factor neutralizing antibody, AMG102. J Cell Mol Med 15:1999-2006, 2011

17. Burgess T, Coxon A, Meyer S, Sun J, Rex K, Tsuruda T, et al: Fully human monoclonal antibodies to hepatocyte growth factor with therapeutic potential against hepatocyte growth factor/c-Met-dependent human tumors. Cancer Res 66:17211729,2006

18. Cantley LC, Neel BG: New insights into tumor suppression: PTEN suppresses tumor formation by restraining the phosphoinositide 3-kinase/AKT pathway. Proc Natl Acad Sci U S A 96:4240-4245, 1999

19. Cao X, Fang L, Gibbs S, Huang Y, Dai Z, Wen P, et al: Glucose uptake inhibitor sensitizes cancer cells to daunorubicin and overcomes drug resistance in hypoxia. Cancer Chemother Pharmacol 59:495-505, 2007

20. Cao XX, Xu JD, Xu JW, Liu XL, Cheng YY, Li QQ, et al: RACK1 promotes breast carcinoma migration/metastasis via activation of the RhoA/Rho kinase pathway. Breast Cancer Res Treat 126:555-563, 2011

21. Carmeliet P, Dor Y, Herbert JM, Fukumura D, Brusselmans K, Dewerchin M, et al: Role of HIF-1alpha in hypoxia-mediated apoptosis, cell proliferation and tumour angiogenesis. Nature 394:485-490, 1998 (Erratum in Nature 395:525, 1998)

22. Ceradini DJ, Kulkarni AR, Callaghan MJ, Tepper OM, Bastidas N, Kleinman ME, et al: Progenitor cell trafficking is regulated by hypoxic gradients through HIF-1 induction of SDF-1. Nat Med 10:858-864, 2004

23. Chakravarti A, Zhai G, Suzuki Y, Sarkesh S, Black PM, Muzikansky A, et al: The prognostic significance of phosphatidylinositol 3-kinase pathway activation in human gliomas. J Clin Oncol 22:1926-1933, 2004

24. Chen F, Kishida T, Duh FM, Renbaum P, Orcutt ML, Schmidt L, et al: Suppression of growth of renal carcinoma cells by the von Hippel-Lindau tumor suppressor gene. Cancer Res 55: 4804-4807, 1995

25. Chen L, Han L, Zhang K, Shi Z, Zhang J, Zhang A, et al: VHL regulates the effects of miR-23b on glioma survival and in- 
vasion via suppression of HIF-1 $\alpha /$ VEGF and $\beta$-catenin/Tcf- 4 signaling. Neuro Oncol 14:1026-1036, 2012

26. Chen Z, Htay A, Dos Santos W, Gillies GT, Fillmore HL, Sholley MM, et al: In vitro angiogenesis by human umbilical vein endothelial cells (HUVEC) induced by three-dimensional co-culture with glioblastoma cells. J Neurooncol 92:121128,2009

27. Chesnelong C, Chaumeil MM, Blough MD, Al-Najjar M, Stechishin OD, Chan JA, et al: Lactate dehydrogenase A silencing in IDH mutant gliomas. Neuro Oncol 16:686-695, 2014

28. Chiavarina B, Whitaker-Menezes D, Migneco G, MartinezOutschoorn UE, Pavlides S, Howell A, et al: HIF1-alpha functions as a tumor promoter in cancer associated fibroblasts, and as a tumor suppressor in breast cancer cells: autophagy drives compartment-specific oncogenesis. Cell Cycle 9:3534-3551, 2010

29. Cho KH, Choi MJ, Jeong KJ, Kim JJ, Hwang MH, Shin SC, et al: A ROS/STAT3/HIF-1 $\alpha$ signaling cascade mediates EGFinduced TWIST1 expression and prostate cancer cell invasion. Prostate 74:528-536, 2014

30. Choe G, Horvath S, Cloughesy TF, Crosby K, Seligson D, Palotie A, et al: Analysis of the phosphatidylinositol 3'-kinase signaling pathway in glioblastoma patients in vivo. Cancer Res 63:2742-2746, 2003

31. Comito G, Calvani M, Giannoni E, Bianchini F, Calorini L, Torre E, et al: HIF-1 $\alpha$ stabilization by mitochondrial ROS promotes Met-dependent invasive growth and vasculogenic mimicry in melanoma cells. Free Radic Biol Med 51:893904, 2011

32. Cooper R, Sarioğlu S, Sökmen S, Füzün M, Küpelioğlu A, Valentine H, et al: Glucose transporter-1 (GLUT-1): a potential marker of prognosis in rectal carcinoma? Br J Cancer 89: 870-876, 2003

33. Cuvier C, Jang A, Hill RP: Exposure to hypoxia, glucose starvation and acidosis: effect on invasive capacity of murine tumor cells and correlation with cathepsin $(\mathrm{L}+\mathrm{B})$ secretion. Clin Exp Metastasis 15:19-25, 1997

34. Davis M, Pragani R, Popovici-Muller J, Gross S, Thorne N, Salituro F, et al: ML309: a potent inhibitor of R132H mutant IDH1 capable of reducing 2-hydroxyglutarate production in U87 MG glioblastoma cells, in Probe Reports from the NIH Molecular Libraries Program. Bethesda, MD: National Center for Biotechnology Information, 2010

35. Davis MI, Gross S, Shen M, Straley KS, Pragani R, Lea WA, et al: Biochemical, cellular, and biophysical characterization of a potent inhibitor of mutant isocitrate dehydrogenase IDH1. J Biol Chem 289:13717-13725, 2014

36. De Bacco F, Casanova E, Medico E, Pellegatta S, Orzan F, Albano R, et al: The MET oncogene is a functional marker of a glioblastoma stem cell subtype. Cancer Res 72:4537-4550, 2012

37. De Falco E, Porcelli D, Torella AR, Straino S, Iachininoto MG, Orlandi A, et al: SDF-1 involvement in endothelial phenotype and ischemia-induced recruitment of bone marrow progenitor cells. Blood 104:3472-3482, 2004

38. Del Bufalo D, Ciuffreda L, Trisciuoglio D, Desideri M, Cognetti F, Zupi G, et al: Antiangiogenic potential of the Mammalian target of rapamycin inhibitor temsirolimus. Cancer Res 66:5549-5554, 2006

39. Du R, Lu KV, Petritsch C, Liu P, Ganss R, Passegué E, et al: HIFlalpha induces the recruitment of bone marrow-derived vascular modulatory cells to regulate tumor angiogenesis and invasion. Cancer Cell 13:206-220, 2008

40. Duan Y, Zhao X, Ren W, Wang X, Yu KF, Li D, et al: Antitumor activity of dichloroacetate on C6 glioma cell: in vitro and in vivo evaluation. Onco Targets Ther 6:189-198, 2013

41. Eckerich C, Zapf S, Fillbrandt R, Loges S, Westphal M, Lamszus K: Hypoxia can induce c-Met expression in glioma cells and enhance SF/HGF-induced cell migration. Int $\mathbf{J}$ Cancer 121:276-283, 2007
42. El Sayed SM, Abou El-Magd RM, Shishido Y, Chung SP, Sakai T, Watanabe H, et al: D-amino acid oxidase gene therapy sensitizes glioma cells to the antiglycolytic effect of 3-bromopyruvate. Cancer Gene Ther 19:1-18, 2012

43. El Sayed SM, El-Magd RM, Shishido Y, Chung SP, Diem TH, Sakai T, et al: 3-Bromopyruvate antagonizes effects of lactate and pyruvate, synergizes with citrate and exerts novel antiglioma effects. J Bioenerg Biomembr 44:61-79, 2012

44. El Sayed SM, El-Magd RM, Shishido Y, Yorita K, Chung SP, Tran DH, et al: D-Amino acid oxidase-induced oxidative stress, 3-bromopyruvate and citrate inhibit angiogenesis, exhibiting potent anticancer effects. J Bioenerg Biomembr 44:513-523, 2012

45. Evans A, Bates V, Troy H, Hewitt S, Holbeck S, Chung YL, et al: Glut-1 as a therapeutic target: increased chemoresistance and HIF-1-independent link with cell turnover is revealed through COMPARE analysis and metabolomic studies. Cancer Chemother Pharmacol 61:377-393, 2008

46. Eyler CE, Rich JN: Survival of the fittest: cancer stem cells in therapeutic resistance and angiogenesis. J Clin Oncol 26: 2839-2845, 2008

47. Ezhilarasan R, Mohanam I, Govindarajan K, Mohanam S: Glioma cells suppress hypoxia-induced endothelial cell apoptosis and promote the angiogenic process. Int J Oncol 30: 701-707, 2007

48. Fang J, Xia C, Cao Z, Zheng JZ, Reed E, Jiang BH: Apigenin inhibits VEGF and HIF-1 expression via PI3K/AKT/p70S6K1 and HDM2/p53 pathways. FASEB J 19:342-353, 2005

49. Flynn JR, Wang L, Gillespie DL, Stoddard GJ, Reid JK, Owens J, et al: Hypoxia-regulated protein expression, patient characteristics, and preoperative imaging as predictors of survival in adults with glioblastoma multiforme. Cancer 113: 1032-1042, 2008

50. Folkins C, Shaked Y, Man S, Tang T, Lee CR, Zhu Z, et al: Glioma tumor stem-like cells promote tumor angiogenesis and vasculogenesis via vascular endothelial growth factor and stromal-derived factor 1. Cancer Res 69:7243-7251, 2009

51. Forsythe JA, Jiang BH, Iyer NV, Agani F, Leung SW, Koos $\mathrm{RD}$, et al: Activation of vascular endothelial growth factor gene transcription by hypoxia-inducible factor 1 . Mol Cell Biol 16:4604-4613, 1996

52. Franovic A, Holterman CE, Payette J, Lee S: Human cancers converge at the HIF-2alpha oncogenic axis. Proc Natl Acad Sci U S A 106:21306-21311, 2009

53. Fujiwara K, Iwado E, Mills GB, Sawaya R, Kondo S, Kondo $Y$ : Akt inhibitor shows anticancer and radiosensitizing effects in malignant glioma cells by inducing autophagy. Int J Oncol 31:753-760, 2007

54. Fujiwara S, Nakagawa K, Harada H, Nagato S, Furukawa K, Teraoka M, et al: Silencing hypoxia-inducible factor-1alpha inhibits cell migration and invasion under hypoxic environment in malignant gliomas. Int J Oncol 30:793-802, 2007

55. Fults D, Pedone CA, Thompson GE, Uchiyama CM, Gumpper $\mathrm{KL}$, Iliev D, et al: Microsatellite deletion mapping on chromosome 10q and mutation analysis of MMAC1, FAS, and MXI1 in human glioblastoma multiforme. Int J Oncol 12:905-910, 1998

56. Furuta T, Nakada M, Misaki K, Sato Y, Hayashi Y, Nakanuma Y, et al: Molecular analysis of a recurrent glioblastoma treated with bevacizumab. Brain Tumor Pathol 31:32-39, 2014

57. Gadducci A, Guerrieri ME, Greco C: Tissue biomarkers as prognostic variables of cervical cancer. Crit Rev Oncol Hematol 86:104-129, 2013

58. Gaspar N, Sharp SY, Eccles SA, Gowan S, Popov S, Jones C, et al: Mechanistic evaluation of the novel HSP90 inhibitor NVP-AUY922 in adult and pediatric glioblastoma. Mol Cancer Ther 9:1219-1233, 2010

59. Gatenby RA, Kessler HB, Rosenblum JS, Coia LR, Moldofsky PJ, Hartz WH, et al: Oxygen distribution in squamous cell car- 
cinoma metastases and its relationship to outcome of radiation therapy. Int J Radiat Oncol Biol Phys 14:831-838, 1988

60. Gillespie D, Arce-Larreta M, Ravichandran S, Leishman L, Berrondo C, Gamboa J, et al: RNA interference targeting HIF-1a via a novel multifunctional surfactant attenuates glioma growth in an intracranial mouse model. J Neurosurg [in press]

61. Gillespie DL, Whang K, Ragel BT, Flynn JR, Kelly DA, Jensen RL: Silencing of hypoxia inducible factor-1alpha by RNA interference attenuates human glioma cell growth in vivo. Clin Cancer Res 13:2441-2448, 2007

62. Gnarra JR, Zhou S, Merrill MJ, Wagner JR, Krumm A, Papavassiliou E, et al: Post-transcriptional regulation of vascular endothelial growth factor mRNA by the product of the VHL tumor suppressor gene. Proc Natl Acad Sci U S A 93:1058910594, 1996

63. Graham CH, Forsdike J, Fitzgerald CJ, Macdonald-Goodfellow S: Hypoxia-mediated stimulation of carcinoma cell invasiveness via upregulation of urokinase receptor expression. Int J Cancer 80:617-623, 1999

64. Grosso S, Doyen J, Parks SK, Bertero T, Paye A, Cardinaud B, et al: MiR-210 promotes a hypoxic phenotype and increases radioresistance in human lung cancer cell lines. Cell Death Dis 4:e544, 2013

65. Guessous F, Zhang Y, diPierro C, Marcinkiewicz L, Sarkaria J, Schiff D, et al: An orally bioavailable c-Met kinase inhibitor potently inhibits brain tumor malignancy and growth. Anticancer Agents Med Chem 10:28-35, 2010

66. Guo J, Shinriki S, Su Y, Nakamura T, Hayashi M, Tsuda Y, et al: Hypoxia suppresses cylindromatosis (CYLD) expression to promote inflammation in glioblastoma: possible link to acquired resistance to anti-VEGF therapy. Oncotarget 15: 6353-6364, 2014

67. Haase VH: The VHL/HIF oxygen-sensing pathway and its relevance to kidney disease. Kidney Int 69:1302-1307, 2006

68. Han JY, Oh SH, Morgillo F, Myers JN, Kim E, Hong WK, et al: Hypoxia-inducible factor lalpha and antiangiogenic activity of farnesyltransferase inhibitor SCH66336 in human aerodigestive tract cancer. J Natl Cancer Inst 97:1272-1286, 2005

69. Harada H: How can we overcome tumor hypoxia in radiation therapy? J Radiat Res (Tokyo) 52:545-556, 2011

70. He G, Jiang Y, Zhang B, Wu G: The effect of HIF-1 $\alpha$ on glucose metabolism, growth and apoptosis of pancreatic cancerous cells. Asia Pac J Clin Nutr 23:174-180, 2014

71. Helbig L, Koi L, Brüchner K, Gurtner K, Hess-Stumpp H, Unterschemmann K, et al: Hypoxia-inducible factor pathway inhibition resolves tumor hypoxia and improves local tumor control after single-dose irradiation. Int J Radiat Oncol Biol Phys 88:159-166, 2014

72. Hennessey D, Martin LM, Atzberger A, Lynch TH, Hollywood D, Marignol L: Exposure to hypoxia following irradiation increases radioresistance in prostate cancer cells. Urol Oncol 31:1106-1116, 2013

73. Henze AT, Riedel J, Diem T, Wenner J, Flamme I, Pouyseggur $\mathrm{J}$, et al: Prolyl hydroxylases 2 and 3 act in gliomas as protective negative feedback regulators of hypoxia-inducible factors. Cancer Res 70:357-366, 2010

74. Hewitson KS, McNeill LA, Riordan MV, Tian YM, Bullock AN, Welford RW, et al: Hypoxia-inducible factor (HIF) asparagine hydroxylase is identical to factor inhibiting HIF (FIH) and is related to the cupin structural family. J Biol Chem 277: 26351-26355, 2002

75. Hiddingh L, Raktoe RS, Jeuken J, Hulleman E, Noske DP, Kaspers GJ, et al: Identification of temozolomide resistance factors in glioblastoma via integrative $\mathrm{miRNA} / \mathrm{mRNA}$ regulatory network analysis. Sci Rep 4:5260, 2014

76. Hockel M, Schlenger K, Aral B, Mitze M, Schaffer U, Vaupel P: Association between tumor hypoxia and malignant progression in advanced cancer of the uterine cervix. Cancer Res 56:4509-4515, 1996

77. Höckel M, Schlenger K, Höckel S, Aral B, Schäffer U, Vaupel $\mathrm{P}$ : Tumor hypoxia in pelvic recurrences of cervical cancer. Int J Cancer 79:365-369, 1998

78. Hu F, Tao Z, Wang M, Li G, Zhang Y, Zhong H, et al: RACK1 promoted the growth and migration of the cancer cells in the progression of esophageal squamous cell carcinoma. Tumour Biol 34:3893-3899, 2013

79. Hu YL, DeLay M, Jahangiri A, Molinaro AM, Rose SD, Carbonell WS, et al: Hypoxia-induced autophagy promotes tumor cell survival and adaptation to antiangiogenic treatment in glioblastoma. Cancer Res 72:1773-1783, 2012

80. Huveldt D, Lewis-Tuffin LJ, Carlson BL, Schroeder MA, Rodriguez F, Giannini C, et al: Targeting Src family kinases inhibits bevacizumab-induced glioma cell invasion. PLoS ONE 8:e56505, 2013

81. Ichimura K, Schmidt EE, Miyakawa A, Goike HM, Collins VP: Distinct patterns of deletion on 10p and 10q suggest involvement of multiple tumor suppressor genes in the development of astrocytic gliomas of different malignancy grades. Genes Chromosomes Cancer 22:9-15, 1998

82. Ihnatko R, Kubes M, Takacova M, Sedlakova O, Sedlak J, Pastorek J, et al: Extracellular acidosis elevates carbonic anhydrase IX in human glioblastoma cells via transcriptional modulation that does not depend on hypoxia. Int J Oncol 29: 1025-1033, 2006

83. Ino Y, Yamazaki-Itoh R, Oguro S, Shimada K, Kosuge T, Zavada J, et al: Arginase II expressed in cancer-associated fibroblasts indicates tissue hypoxia and predicts poor outcome in patients with pancreatic cancer. PLoS ONE 8:e55146, 2013

84. Isaacs JS, Jung YJ, Mimnaugh EG, Martinez A, Cuttitta F, Neckers LM: Hsp90 regulates a von Hippel Lindau-independent hypoxia-inducible factor-1 alpha-degradative pathway. J Biol Chem 277:29936-29944, 2002

85. Ivanov S, Liao SY, Ivanova A, Danilkovitch-Miagkova A, Tarasova N, Weirich G, et al: Expression of hypoxia-inducible cell-surface transmembrane carbonic anhydrases in human cancer. Am J Pathol 158:905-919, 2001

86. Jahangiri A, De Lay M, Miller LM, Carbonell WS, Hu YL, $\mathrm{Lu} \mathrm{K}$, et al: Gene expression profile identifies tyrosine kinase c-Met as a targetable mediator of antiangiogenic therapy resistance. Clin Cancer Res 19:1773-1783, 2013

87. Jelluma N, Yang X, Stokoe D, Evan GI, Dansen TB, HaasKogan DA: Glucose withdrawal induces oxidative stress followed by apoptosis in glioblastoma cells but not in normal human astrocytes. Mol Cancer Res 4:319-330, 2006

88. Jensen RL: Brain tumor hypoxia: tumorigenesis, angiogenesis, imaging, pseudoprogression, and as a therapeutic target. J Neurooncol 92:317-335, 2009

89. Jensen RL: Hypoxia in the tumorigenesis of gliomas and as a potential target for therapeutic measures. Neurosurg Focus 20(4):E24, 2006

90. Jeong JW, Bae MK, Ahn MY, Kim SH, Sohn TK, Bae MH, et al: Regulation and destabilization of HIF-1alpha by ARD1mediated acetylation. Cell 111:709-720, 2002

91. Jha MK, Suk K: Pyruvate dehydrogenase kinase as a potential therapeutic target for malignant gliomas. Brain Tumor Res Treat 1:57-63, 2013

92. Jhaveri N, Cho H, Torres S, Wang W, Schönthal AH, Petasis NA, et al: Noscapine inhibits tumor growth in TMZ-resistant gliomas. Cancer Lett 312:245-252, 2011

93. Jiang BH, Rue E, Wang GL, Roe R, Semenza GL: Dimerization, DNA binding, and transactivation properties of hypoxiainducible factor 1. J Biol Chem 271:17771-17778, 1996

94. Jin J, Bae KH, Yang H, Lee SJ, Kim H, Kim Y, et al: In vivo specific delivery of c-Met siRNA to glioblastoma using cationic solid lipid nanoparticles. Bioconjug Chem 22:25682572,2011 
95. Joo KM, Jin J, Kim E, Ho Kim K, Kim Y, Gu Kang B, et al: MET signaling regulates glioblastoma stem cells. Cancer Res 72:3828-3838, 2012

96. Jun HJ, Bronson RT, Charest A: Inhibition of EGFR induces a c-MET-driven stem cell population in glioblastoma. Stem Cells 32:338-348, 2014

97. Jun HT, Sun J, Rex K, Radinsky R, Kendall R, Coxon A, et al: AMG 102, a fully human anti-hepatocyte growth factor/scatter factor neutralizing antibody, enhances the efficacy of temozolomide or docetaxel in U-87 MG cells and xenografts. Clin Cancer Res 13:6735-6742, 2007

98. Kaelin WG Jr: Molecular basis of the VHL hereditary cancer syndrome. Nat Rev Cancer 2:673-682, 2002

99. Kaluz S, Kaluzová M, Stanbridge EJ: Proteasomal inhibition attenuates transcriptional activity of hypoxia-inducible factor 1 (HIF-1) via specific effect on the HIF-1alpha C-terminal activation domain. Mol Cell Biol 26:5895-5907, 2006

100. Kaluz S, Van Meir EG: At the crossroads of cancer and inflammation: Ras rewires an HIF-driven IL-1 autocrine loop. J Mol Med (Berl) 89:91-94, 2011

101. Kanno H, Sato H, Yokoyama TA, Yoshizumi T, Yamada S: The VHL tumor suppressor protein regulates tumorigenicity of U87-derived glioma stem-like cells by inhibiting the JAK/STAT signaling pathway. Int J Oncol 42:881-886, 2013

102. Kaur B, Khwaja FW, Severson EA, Matheny SL, Brat DJ, Van Meir EG: Hypoxia and the hypoxia-inducible-factor pathway in glioma growth and angiogenesis. Neuro Oncol 7:134-153, 2005

103. Keith B, Johnson RS, Simon MC: HIF1 $\alpha$ and HIF2 $\alpha$ : sibling rivalry in hypoxic tumour growth and progression. Nat Rev Cancer 12:9-22, 2012

104. Kessler J, Hahnel A, Wichmann H, Rot S, Kappler M, Bache $\mathrm{M}$, et al: HIF-1 $\alpha$ inhibition by siRNA or chetomin in human malignant glioma cells: effects on hypoxic radioresistance and monitoring via CA9 expression. BMC Cancer 10:605, 2010

105. Keunen O, Johansson M, Oudin A, Sanzey M, Rahim SA, Fack F, et al: Anti-VEGF treatment reduces blood supply and increases tumor cell invasion in glioblastoma. Proc Natl Acad Sci U S A 108:3749-3754, 2011

106. Kietzmann T, Krones-Herzig A, Jungermann K: Signaling cross-talk between hypoxia and glucose via hypoxia-inducible factor 1 and glucose response elements. Biochem Pharmacol 64:903-911, 2002

107. Kim KJ, Wang L, Su YC, Gillespie GY, Salhotra A, Lal B, et al: Systemic anti-hepatocyte growth factor monoclonal antibody therapy induces the regression of intracranial glioma xenografts. Clin Cancer Res 12:1292-1298, 2006

108. Kimura H, Weisz A, Kurashima Y, Hashimoto K, Ogura T, D'Acquisto F, et al: Hypoxia response element of the human vascular endothelial growth factor gene mediates transcriptional regulation by nitric oxide: control of hypoxia-inducible factor-1 activity by nitric oxide. Blood 95:189-197, 2000

109. Koh MY, Powis G: Passing the baton: the HIF switch. Trends Biochem Sci 37:364-372, 2012

110. Koivunen P, Lee S, Duncan CG, Lopez G, Lu G, Ramkissoon $\mathrm{S}$, et al: Transformation by the (R)-enantiomer of 2-hydroxyglutarate linked to EGLN activation. Nature 483:484-488, 2012

111. Kondo K, Klco J, Nakamura E, Lechpammer M, Kaelin WG Jr: Inhibition of HIF is necessary for tumor suppression by the von Hippel-Lindau protein. Cancer Cell 1:237-246, 2002

112. Koul D: PTEN signaling pathways in glioblastoma. Cancer Biol Ther 7:1321-1325, 2008

113. Krieg M, Haas R, Brauch H, Acker T, Flamme I, Plate KH: Up-regulation of hypoxia-inducible factors HIF-1alpha and HIF-2alpha under normoxic conditions in renal carcinoma cells by von Hippel-Lindau tumor suppressor gene loss of function. Oncogene 19:5435-5443, 2000

114. Kumar K, Wigfield S, Gee HE, Devlin CM, Singleton D, Li JL, et al: Dichloroacetate reverses the hypoxic adaptation to bevacizumab and enhances its antitumor effects in mouse xenografts. $\mathbf{J}$ Mol Med (Berl) 91:749-758, 2013

115. Kumar S, Arbab AS: Neovascularization in glioblastoma: current pitfall in anti-angiogenic therapy. Zhong Liu Za Zhi 1:16-19, 2013

116. Kwon HS, Kim DR, Yang EG, Park YK, Ahn HC, Min SJ, et al: Inhibition of VEGF transcription through blockade of the hypoxia inducible factor- $1 \alpha-$ p300 interaction by a small molecule. Bioorg Med Chem Lett 22:5249-5252, 2012

117. Lal A, Peters H, St Croix B, Haroon ZA, Dewhirst MW, Strausberg RL, et al: Transcriptional response to hypoxia in human tumors. J Natl Cancer Inst 93:1337-1343, 2001

118. Lal B, Xia S, Abounader R, Laterra J: Targeting the c-Met pathway potentiates glioblastoma responses to gamma-radiation. Clin Cancer Res 11:4479-4486, 2005

119. LaVallee TM, Burke PA, Swartz GM, Hamel E, Agoston GE, Shah J, et al: Significant antitumor activity in vivo following treatment with the microtubule agent ENMD-1198. Mol Cancer Ther 7:1472-1482, 2008

120. Lawrence RE, Salgia R: MET molecular mechanisms and therapies in lung cancer. Cell Adhes Migr 4:146-152, 2010

121. Le A, Cooper CR, Gouw AM, Dinavahi R, Maitra A, Deck LM, et al: Inhibition of lactate dehydrogenase A induces oxidative stress and inhibits tumor progression. Proc Natl Acad Sci U S A 107:2037-2042, 2010

122. Lee K, Kim HM: A novel approach to cancer therapy using PX-478 as a HIF-1 $\alpha$ inhibitor. Arch Pharm Res 34:1583-1585, 2011

123. Leibel SA, Scott CB, Loeffler JS: Contemporary approaches to the treatment of malignant gliomas with radiation therapy. Semin Oncol 21:198-219, 1994

124. Li C, Liu Y, Liu J, Chen Y, Li Z, Chen X, et al: Rapamycin inhibits human glioma cell proliferation through down-regulating mammalian target of rapamycin pathway and up-regulating microRNA-143. Head Neck Oncol 4:66, 2012

125. Li DW, Zhou L, Jin B, Xie J, Dong P: Expression and significance of hypoxia-inducible factor-1 $\alpha$ and survivin in laryngeal carcinoma tissue and cells. Otolaryngol Head Neck Surg 148: 75-81, 2013

126. Li J, Guo Y, Feng X, Wang Z, Wang Y, Deng P, et al: Receptor for activated $\mathrm{C}$ kinase 1 (RACK1): a regulator for migration and invasion in oral squamous cell carcinoma cells. J Cancer Res Clin Oncol 138:563-571, 2012

127. Li J, Yen C, Liaw D, Podsypanina K, Bose S, Wang SI, et al: PTEN, a putative protein tyrosine phosphatase gene mutated in human brain, breast, and prostate cancer. Science 275:19431947,1997

128. Li Y, Li A, Glas M, Lal B, Ying M, Sang Y, et al: c-Met signaling induces a reprogramming network and supports the glioblastoma stem-like phenotype. Proc Natl Acad Sci U S A 108: 9951-9956, 2011

129. Li Z, Bao S, Wu Q, Wang H, Eyler C, Sathornsumetee S, et al: Hypoxia-inducible factors regulate tumorigenic capacity of glioma stem cells. Cancer Cell 15:501-513, 2009

130. Liu H, Li Y, Raisch KP: Clotrimazole induces a late G1 cell cycle arrest and sensitizes glioblastoma cells to radiation in vitro. Anticancer Drugs 21:841-849, 2010

131. Liu YV, Baek JH, Zhang H, Diez R, Cole RN, Semenza GL: RACK1 competes with HSP90 for binding to HIF-1alpha and is required for $\mathrm{O}(2)$-independent and HSP90 inhibitor-induced degradation of HIF-1alpha. Mol Cell 25:207-217, 2007

132. Lu H, Forbes RA, Verma A: Hypoxia-inducible factor 1 activation by aerobic glycolysis implicates the Warburg effect in carcinogenesis. J Biol Chem 277:23111-23115, 2002

133. Lu J, Zhang K, Chen S, Wen W: Grape seed extract inhibits VEGF expression via reducing HIF-1alpha protein expression. Carcinogenesis 30:636-644, 2009 
134. Lu KV, Bergers G: Mechanisms of evasive resistance to antiVEGF therapy in glioblastoma. CNS Oncol 2:49-65, 2013

135. Luwor RB, Stylli SS, Kaye AH: The role of Stat 3 in glioblastoma multiforme. J Clin Neurosci 20:907-911, 2013

136. Mabjeesh NJ, Escuin D, LaVallee TM, Pribluda VS, Swartz GM, Johnson MS, et al: 2ME2 inhibits tumor growth and angiogenesis by disrupting microtubules and dysregulating HIF. Cancer Cell 3:363-375, 2003

137. Mabjeesh NJ, Post DE, Willard MT, Kaur B, Van Meir EG, Simons JW, et al: Geldanamycin induces degradation of hypoxia-inducible factor 1alpha protein via the proteosome pathway in prostate cancer cells. Cancer Res 62:2478-2482, 2002

138. Mack FA, Rathmell WK, Arsham AM, Gnarra J, Keith B, Simon MC: Loss of pVHL is sufficient to cause HIF dysregulation in primary cells but does not promote tumor growth. Cancer Cell 3:75-88, 2003

139. Madan J, Pandey RS, Jain V, Katare OP, Chandra R, Katyal A: Poly (ethylene)-glycol conjugated solid lipid nanoparticles of noscapine improve biological half-life, brain delivery and efficacy in glioblastoma cells. Nanomedicine (Lond Print) 9: 492-503, 2013

140. Mahon PC, Hirota K, Semenza GL: FIH-1: a novel protein that interacts with HIF-1alpha and VHL to mediate repression of HIF-1 transcriptional activity. Genes Dev 15:2675-2686, 2001

141. Majumder PK, Febbo PG, Bikoff R, Berger R, Xue Q, McMahon $\mathrm{LM}$, et al: mTOR inhibition reverses Akt-dependent prostate intraepithelial neoplasia through regulation of apoptotic and HIF1-dependent pathways. Nat Med 10:594-601, 2004

142. Martell RL, Slapak CA, Levy SB: Effect of glucose transport inhibitors on vincristine efflux in multidrug-resistant murine erythroleukaemia cells overexpressing the multidrug resistanceassociated protein (MRP) and two glucose transport proteins, GLUT1 and GLUT3. Br J Cancer 75:161-168, 1997

143. Martens T, Schmidt NO, Eckerich C, Fillbrandt R, Merchant M, Schwall R, et al: A novel one-armed anti-c-Met antibody inhibits glioblastoma growth in vivo. Clin Cancer Res 12:6144-6152, 2006

144. Masui K, Cavenee WK, Mischel PS: mTORC2 dictates Warburg effect and drug resistance. Cell Cycle 13:1053-1054, 2014

145. Masui K, Tanaka K, Akhavan D, Babic I, Gini B, Matsutani T, et al: mTOR complex 2 controls glycolytic metabolism in glioblastoma through FoxO acetylation and upregulation of c-Myc. Cell Metab 18:726-739, 2013

146. Maxwell PH, Wiesener MS, Chang GW, Clifford SC, Vaux EC, Cockman ME, et al: The tumour suppressor protein VHL targets hypoxia-inducible factors for oxygen-dependent proteolysis. Nature 399:271-275, 1999

147. McCarty JH: Glioblastoma resistance to anti-VEGF therapy: has the challenge been MET? Clin Cancer Res 19:1631-1633, 2013

148. McIntyre A, Patiar S, Wigfield S, Li JL, Ledaki I, Turley H, et al: Carbonic anhydrase IX promotes tumor growth and necrosis in vivo and inhibition enhances anti-VEGF therapy. Clin Cancer Res 18:3100-3111, 2012

149. Meijer TW, Kaanders JH, Span PN, Bussink J: Targeting hypoxia, HIF-1, and tumor glucose metabolism to improve radiotherapy efficacy. Clin Cancer Res 18:5585-5594, 2012

150. Merighi S, Benini A, Mirandola P, Gessi S, Varani K, Leung E, et al: Hypoxia inhibits paclitaxel-induced apoptosis through adenosine-mediated phosphorylation of bad in glioblastoma cells. Mol Pharmacol 72:162-172, 2007

151. Michaud NR, Jani JP, Hillerman S, Tsaparikos KE, BarbacciTobin EG, Knauth E, et al: Biochemical and pharmacological characterization of human c-Met neutralizing monoclonal antibody CE-355621. MAbs 4:710-723, 2012

152. Michelakis ED, Sutendra G, Dromparis P, Webster L, Haromy A, Niven E, et al: Metabolic modulation of glioblastoma with dichloroacetate. Sci Transl Med 2:31ra34, 2010
153. Mie Lee Y, Kim SH, Kim HS, Jin Son M, Nakajima H, Jeong Kwon $\mathrm{H}$, et al: Inhibition of hypoxia-induced angiogenesis by FK228, a specific histone deacetylase inhibitor, via suppression of HIF-1alpha activity. Biochem Biophys Res Commun 300: 241-246, 2003

154. Miekus K, Kijowski J, Sekuła M, Majka M: 17AEP-GA, an HSP90 antagonist, is a potent inhibitor of glioblastoma cell proliferation, survival, migration and invasion. Oncol Rep 28: 1903-1909, 2012

155. Milanović D, Firat E, Grosu AL, Niedermann G: Increased radiosensitivity and radiothermosensitivity of human pancreatic MIA PaCa-2 and U251 glioblastoma cell lines treated with the novel Hsp90 inhibitor NVP-HSP990. Radiat Oncol 8:42, 2013

156. Mirimanoff RO: The evolution of chemoradiation for glioblastoma: a modern success story. Curr Oncol Rep 8:50-53, 2006

157. Morfouace M, Lalier L, Bahut M, Bonnamain V, Naveilhan P, Guette C, et al: Comparison of spheroids formed by rat glioma stem cells and neural stem cells reveals differences in glucose metabolism and promising therapeutic applications. J Biol Chem 287:33664-33674, 2012

158. Na YR, Han KC, Park H, Yang EG: Menadione and ethacrynic acid inhibit the hypoxia-inducible factor (HIF) pathway by disrupting HIF-1 $\alpha$ interaction with p300. Biochem Biophys Res Commun 434:879-884, 2013

159. Nakamizo A, Marini F, Amano T, Khan A, Studeny M, Gumin $\mathrm{J}$, et al: Human bone marrow-derived mesenchymal stem cells in the treatment of gliomas. Cancer Res 65:3307-3318, 2005

160. Nardinocchi L, Pantisano V, Puca R, Porru M, Aiello A, Grasselli A, et al: Zinc downregulates HIF-1 $\alpha$ and inhibits its activity in tumor cells in vitro and in vivo. PLoS ONE 5:e15048, 2010

161. Narita T, Yin S, Gelin CF, Moreno CS, Yepes M, Nicolaou KC, et al: Identification of a novel small molecule HIF-1alpha translation inhibitor. Clin Cancer Res 15:6128-6136, 2009

162. Navis AC, Bourgonje A, Wesseling P, Wright A, Hendriks W, Verrijp K, et al: Effects of dual targeting of tumor cells and stroma in human glioblastoma xenografts with a tyrosine kinase inhibitor against c-MET and VEGFR2. PLoS ONE 8:e58262, 2013

163. Newcomb EW, Lukyanov Y, Smirnova I, Schnee T, Zagzag D: Noscapine induces apoptosis in human glioma cells by an apoptosis-inducing factor-dependent pathway. Anticancer Drugs 19:553-563, 2008

164. Nishioka T, Oda Y, Seino Y, Yamamoto T, Inagaki N, Yano $\mathrm{H}$, et al: Distribution of the glucose transporters in human brain tumors. Cancer Res 52:3972-3979, 1992

165. Nobusawa S, Watanabe T, Kleihues P, Ohgaki H: IDH1 mutations as molecular signature and predictive factor of secondary glioblastomas. Clin Cancer Res 15:6002-6007, 2009

166. Ohgaki H, Kleihues P: The definition of primary and secondary glioblastoma. Clin Cancer Res 19:764-772, 2013

167. Ohh M, Park CW, Ivan M, Hoffman MA, Kim TY, Huang LE, et al: Ubiquitination of hypoxia-inducible factor requires direct binding to the beta-domain of the von Hippel-Lindau protein. Nat Cell Biol 2:423-427, 2000

168. Olmez OF, Cubukcu E, Evrensel T, Kurt M, Avci N, Tolunay $\mathrm{S}$, et al: The immunohistochemical expression of c-Met is an independent predictor of survival in patients with glioblastoma multiforme. Clin Transl Oncol 16:173-177, 2014

169. Onnis B, Rapisarda A, Melillo G: Development of HIF-1 inhibitors for cancer therapy. J Cell Mol Med 13 (9A):2780-2786, 2009

170. Osada M, Imaoka S, Funae Y: Apigenin suppresses the expression of VEGF, an important factor for angiogenesis, in endothelial cells via degradation of HIF-1alpha protein. FEBS Lett 575: 59-63, 2004

171. Peng R, Jiang B, Ma J, Ma Z, Wan X, Liu H, et al: Forced downregulation of RACK1 inhibits glioma development by suppressing Src/Akt signaling activity. Oncol Rep 30:2195-2202, 2013 
172. Petit I, Jin D, Rafii S: The SDF-1-CXCR4 signaling pathway: a molecular hub modulating neo-angiogenesis. Trends Immunol 28:299-307, 2007

173. Piao Y, Liang J, Holmes L, Henry V, Sulman E, de Groot JF: Acquired resistance to anti-VEGF therapy in glioblastoma is associated with a mesenchymal transition. Clin Cancer Res 19: 4392-4403, 2013

174. Polivka J, Polivka J Jr, Rohan V, Pesta M, Repik T, Pitule P, et al: Isocitrate dehydrogenase-1 mutations as prognostic biomarker in glioblastoma multiforme patients in West Bohemia. Biomed Res Int 2014:735659, 2014

175. Pollard PJ, Brière JJ, Alam NA, Barwell J, Barclay E, Wortham $\mathrm{NC}$, et al: Accumulation of Krebs cycle intermediates and overexpression of HIF1alpha in tumours which result from germline FH and SDH mutations. Hum Mol Genet 14:2231-2239, 2005

176. Pore N, Gupta AK, Cerniglia GJ, Maity A: HIV protease inhibitors decrease VEGF/HIF-1alpha expression and angiogenesis in glioblastoma cells. Neoplasia 8:889-895, 2006

177. Porter JR, Ge J, Lee J, Normant E, West K: Ansamycin inhibitors of Hsp90: nature's prototype for anti-chaperone therapy. Curr Top Med Chem 9:1386-1418, 2009

178. Poteet E, Choudhury GR, Winters A, Li W, Ryou MG, Liu R, et al: Reversing the Warburg effect as a treatment for glioblastoma. J Biol Chem 288:9153-9164, 2013

179. Potter CP, Harris AL: Diagnostic, prognostic and therapeutic implications of carbonic anhydrases in cancer. Br J Cancer 89: 2-7, 2003

180. Proescholdt MA, Merrill MJ, Stoerr EM, Lohmeier A, Pohl F, Brawanski A: Function of carbonic anhydrase IX in glioblastoma multiforme. Neuro Oncol 14:1357-1366, 2012

181. Qi Q, Liu X, Li S, Joshi HC, Ye K: Synergistic suppression of noscapine and conventional chemotherapeutics on human glioblastoma cell growth. Acta Pharmacol Sin 34:930-938, 2013

182. Rapisarda A, Uranchimeg B, Sordet O, Pommier Y, Shoemaker RH, Melillo G: Topoisomerase I-mediated inhibition of hypoxiainducible factor 1: mechanism and therapeutic implications. Cancer Res 64:1475-1482, 2004

183. Rapisarda A, Zalek J, Hollingshead M, Braunschweig T, Uranchimeg B, Bonomi CA, et al: Schedule-dependent inhibition of hypoxia-inducible factor-1alpha protein accumulation, angiogenesis, and tumor growth by topotecan in U251-HRE glioblastoma xenografts. Cancer Res 64:6845-6848, 2004

184. Rastogi S, Banerjee S, Chellappan S, Simon GR: Glut-1 antibodies induce growth arrest and apoptosis in human cancer cell lines. Cancer Lett 257:244-251, 2007

185. Rath P, Lal B, Ajala O, Li Y, Xia S, Kim J, et al: In vivo c-Met pathway inhibition depletes human glioma xenografts of tumorpropagating stem-like cells. Transl Oncol 6:104-111, 2013

186. Raza SM, Fuller GN, Rhee CH, Huang S, Hess K, Zhang W, et al: Identification of necrosis-associated genes in glioblastoma by cDNA microarray analysis. Clin Cancer Res 10:212-221, 2004

187. Reece KM, Richardson ED, Cook KM, Campbell TJ, Pisle ST, Holly AJ, et al: Epidithiodiketopiperazines (ETPs) exhibit in vitro antiangiogenic and in vivo antitumor activity by disrupting the HIF-1 $\alpha /$ p300 complex in a preclinical model of prostate cancer. Mol Cancer 13:91, 2014

188. Rhodes DR, Yu J, Shanker K, Deshpande N, Varambally R, Ghosh D, et al: ONCOMINE: a cancer microarray database and integrated data-mining platform. Neoplasia 6:1-6, 2004

189. Rice GC, Hoy C, Schimke RT: Transient hypoxia enhances the frequency of dihydrofolate reductase gene amplification in Chinese hamster ovary cells. Proc Natl Acad Sci U S A 83: 5978-5982, 1986

190. Richard DE, Berra E, Pouysségur J: Angiogenesis: how a tumor adapts to hypoxia. Biochem Biophys Res Commun 266: 718-722, 1999

191. Robey IF, Lien AD, Welsh SJ, Baggett BK, Gillies RJ: Hypoxiainducible factor-1alpha and the glycolytic phenotype in tumors. Neoplasia 7:324-330, 2005
192. Rong Y, Durden DL, Van Meir EG, Brat DJ: 'Pseudopalisading' necrosis in glioblastoma: a familiar morphologic feature that links vascular pathology, hypoxia, and angiogenesis. J Neuropathol Exp Neurol 65:529-539, 2006

193. Rossetto M, Ciccarino P, Boisselier B, Labussiere M, Sanson M: Metabolism of glioma and IDH1/IDH2 mutations. Rev Neurol (Paris) 167:699-703, 2011

194. Said HM, Hagemann C, Carta F, Katzer A, Polat B, Staab A, et al: Hypoxia induced CA9 inhibitory targeting by two different sulfonamide derivatives including acetazolamide in human glioblastoma. Bioorg Med Chem 21:3949-3957, 2013

195. Sami A, Karsy M: Targeting the PI3K/AKT/mTOR signaling pathway in glioblastoma: novel therapeutic agents and advances in understanding. Tumour Biol 34: 1991-2002, 2013

196. Sanna K, Rofstad EK: Hypoxia-induced resistance to doxorubicin and methotrexate in human melanoma cell lines in vitro. Int J Cancer 58:258-262, 1994

197. Sarkaria JN, Kitange GJ, James CD, Plummer R, Calvert H, Weller M, et al: Mechanisms of chemoresistance to alkylating agents in malignant glioma. Clin Cancer Res 14:2900-2908, 2008

198. Sathornsumetee S, Cao Y, Marcello JE, Herndon JE II, McLendon RE, Desjardins A, et al: Tumor angiogenic and hypoxic profiles predict radiographic response and survival in malignant astrocytoma patients treated with bevacizumab and irinotecan. J Clin Oncol 26:271-278, 2008

199. Selak MA, Armour SM, MacKenzie ED, Boulahbel H, Watson DG, Mansfield KD, et al: Succinate links TCA cycle dysfunction to oncogenesis by inhibiting HIF-alpha prolyl hydroxylase. Cancer Cell 7:77-85, 2005

200. Seliger C, Leukel P, Moeckel S, Jachnik B, Lottaz C, Kreutz M, et al: Lactate-modulated induction of THBS-1 activates transforming growth factor (TGF)-beta2 and migration of glioma cells in vitro. PLoS ONE 8:e78935, 2013

201. Seltzer MJ, Bennett BD, Joshi AD, Gao P, Thomas AG, Ferraris DV, et al: Inhibition of glutaminase preferentially slows growth of glioma cells with mutant IDH1. Cancer Res 70:8981-8987, 2010

202. Semenza GL: HIF-1 mediates metabolic responses to intratumoral hypoxia and oncogenic mutations. J Clin Invest 123: 3664-3671, 2013

203. Semenza GL: HIF-1: upstream and downstream of cancer metabolism. Curr Opin Genet Dev 20:51-56, 2010

204. Semenza GL: Hypoxia-inducible factor 1 (HIF-1) pathway. Sci STKE 2007:cm8, 2007

205. Shao R, Zhang FP, Tian F, Anders Friberg P, Wang X, Sjöland $\mathrm{H}$, et al: Increase of SUMO-1 expression in response to hypoxia: direct interaction with HIF-1alpha in adult mouse brain and heart in vivo. FEBS Lett 569:293-300, 2004

206. Sharma V, Dixit D, Koul N, Mehta VS, Sen E: Ras regulates interleukin- $1 \beta$-induced HIF- $1 \alpha$ transcriptional activity in glioblastoma. J Mol Med (Berl) 89:123-136, 2011

207. Shin DH, Chun YS, Lee DS, Huang LE, Park JW: Bortezomib inhibits tumor adaptation to hypoxia by stimulating the FIHmediated repression of hypoxia-inducible factor-1. Blood 111: 3131-3136, 2008

208. Solaini G, Sgarbi G, Baracca A: Oxidative phosphorylation in cancer cells. Biochim Biophys Acta 1807:534-542, 2011

209. Søndergaard KL, Hilton DA, Penney M, Ollerenshaw M, Demaine AG: Expression of hypoxia-inducible factor 1alpha in tumours of patients with glioblastoma. Neuropathol Appl Neurobiol 28:210-217, 2002

210. Song LP, Zhang J, Wu SF, Huang Y, Zhao Q, Cao JP, et al: Hypoxia-inducible factor-1alpha-induced differentiation of myeloid leukemic cells is its transcriptional activity independent. Oncogene 27:519-527, 2008

211. Sonoda Y, Murakami Y, Tominaga T, Kayama T, Yoshimoto T, Sekiya T: Deletion mapping of chromosome 10 in human glioma. Jpn J Cancer Res 87:363-367, 1996 
M. Womeldorff, D. Gillespie, and R. L. Jensen

212. Span PN, Bussink J, Manders P, Beex LV, Sweep CG: Carbonic anhydrase-9 expression levels and prognosis in human breast cancer: association with treatment outcome. Br J Cancer 89: 271-276, 2003

213. Stancheva G, Goranova T, Laleva M, Kamenova M, Mitkova A, Velinov N, et al: IDH1/IDH2 but not TP53 mutations predict prognosis in Bulgarian glioblastoma patients. Biomed Res Int 2014:654727, 2014

214. Stieber VW, Mehta MP: Advances in radiation therapy for brain tumors. Neurol Clin 25:1005-1033, ix, 2007

215. Stupp R, van den Bent MJ, Hegi ME: Optimal role of temozolomide in the treatment of malignant gliomas. Curr Neurol Neurosci Rep 5:198-206, 2005

216. Stupp R, Weber DC: The role of radio- and chemotherapy in glioblastoma. Onkologie 28:315-317, 2005

217. Subbarayan PR, Wang PG, Lampidis TJ, Ardalan B, Braunschweiger P: Differential expression of Glut $1 \mathrm{mRNA}$ and protein levels correlates with increased sensitivity to the glycoconjugated nitric oxide donor (2-glu-SNAP) in different tumor cell types. J Chemother 20:106-111, 2008

218. Sullivan LB, Martinez-Garcia E, Nguyen H, Mullen AR, Dufour E, Sudarshan S, et al: The proto-oncometabolite fumarate binds glutathione to amplify ROS-dependent signaling. Mol Cell 51:236-248, 2013

219. Sun W, Jelkmann W, Depping R: Prolyl-4-hydroxylase 2 enhances hypoxia-induced glioblastoma cell death by regulating the gene expression of hypoxia-inducible factor- $\alpha$. Cell Death Dis 5:e1322, 2014

220. Sundfør K, Lyng H, Rofstad EK: Tumour hypoxia and vascular density as predictors of metastasis in squamous cell carcinoma of the uterine cervix. Br J Cancer 78:822-827, 1998

221. Sutendra G, Michelakis ED: Pyruvate dehydrogenase kinase as a novel therapeutic target in oncology. Front Oncol 3:38, 2013

222. Tan C, de Noronha RG, Roecker AJ, Pyrzynska B, Khwaja $\mathrm{F}$, Zhang $\mathrm{Z}$, et al: Identification of a novel small-molecule inhibitor of the hypoxia-inducible factor 1 pathway. Cancer Res 65:605-612, 2005

223. Theodoropoulos VE, Lazaris ACh, Sofras F, Gerzelis I, Tsoukala V, Ghikonti I, et al: Hypoxia-inducible factor 1 alpha expression correlates with angiogenesis and unfavorable prognosis in bladder cancer. Eur Urol 46:200-208, 2004

224. Vajkoczy P, Menger MD: Vascular microenvironment in gliomas. Cancer Treat Res 117:249-262, 2004

225. Van Meir EG: Cytokines and tumors of the central nervous system. Glia 15:264-288, 1995

226. Velpula KK, Bhasin A, Asuthkar S, Tsung AJ: Combined targeting of PDK1 and EGFR triggers regression of glioblastoma by reversing the Warburg effect. Cancer Res 73:7277-7289, 2013

227. Verma RP, Hansch C: Camptothecins: a SAR/QSAR study. Chem Rev 109:213-235, 2009

228. Wachsberger PR, Lawrence YR, Liu Y, Rice B, Feo N, Leiby B, et al: Hsp90 inhibition enhances PI-3 kinase inhibition and radiosensitivity in glioblastoma. J Cancer Res Clin Oncol 140:573-582, 2014

229. Walenta S, Wetterling M, Lehrke M, Schwickert G, Sundfør K, Rofstad EK, et al: High lactate levels predict likelihood of metastases, tumor recurrence, and restricted patient survival in human cervical cancers. Cancer Res 60:916-921, 2000

230. Wan X, Shen N, Mendoza A, Khanna C, Helman LJ: CCI-779 inhibits rhabdomyosarcoma xenograft growth by an antiangiogenic mechanism linked to the targeting of mTOR/Hif-1alpha/ VEGF signaling. Neoplasia 8:394-401, 2006

231. Wang E, Zhang C, Polavaram N, Liu F, Wu G, Schroeder MA, et al: The role of factor inhibiting HIF (FIH-1) in inhibiting HIF-1 transcriptional activity in glioblastoma multiforme. PLoS ONE 9:e86102, 2014

232. Wang F, Osawa $T$, Tsuchida R, Yuasa Y, Shibuya M: Downregulation of receptor for activated C-kinase 1 (RACK1) suppresses tumor growth by inhibiting tumor cell proliferation and tumor-associated angiogenesis. Cancer Sci 102:2007-2013, 2011

233. Wang GL, Jiang BH, Rue EA, Semenza GL: Hypoxia-inducible factor 1 is a basic-helix-loop-helix-PAS heterodimer regulated by cellular O2 tension. Proc Natl Acad Sci U S A 92:55105514, 1995

234. Wang Q, Hu DF, Rui Y, Jiang AB, Liu ZL, Huang LN: Prognosis value of HIF-1 $\alpha$ expression in patients with non-small cell lung cancer. Gene 541:69-74, 2014

235. Warburg O: On the origin of cancer cells. Science 123:309-314, 1956

236. Welsh JW, Mahadevan D, Ellsworth R, Cooke L, Bearss D, Stea $\mathrm{B}$ : The c-Met receptor tyrosine kinase inhibitor MP470 radiosensitizes glioblastoma cells. Radiat Oncol 4:69, 2009

237. Welsh SJ, Williams RR, Birmingham A, Newman DJ, Kirkpatrick DL, Powis G: The thioredoxin redox inhibitors 1-methylpropyl 2-imidazolyl disulfide and pleurotin inhibit hypoxia-induced factor 1alpha and vascular endothelial growth factor formation. Mol Cancer Ther 2:235-243, 2003

238. Wicks RT, Azadi J, Mangraviti A, Zhang I, Hwang L, Joshi A, et al: Local delivery of cancer-cell glycolytic inhibitors in highgrade glioma. Neuro Oncol [epub ahead of print], 2014

239. Wilson RE, Keng PC, Sutherland RM: Drug resistance in Chinese hamster ovary cells during recovery from severe hypoxia. J Natl Cancer Inst 81:1235-1240, 1989

240. Wolf A, Agnihotri S, Guha A: Targeting metabolic remodeling in glioblastoma multiforme. Oncotarget 1:552-562, 2010

241. Wolf A, Agnihotri S, Micallef J, Mukherjee J, Sabha N, Cairns $\mathrm{R}$, et al: Hexokinase 2 is a key mediator of aerobic glycolysis and promotes tumor growth in human glioblastoma multiforme. J Exp Med 208:313-326, 2011

242. Wolf A, Agnihotri S, Munoz D, Guha A: Developmental profile and regulation of the glycolytic enzyme hexokinase 2 in normal brain and glioblastoma multiforme. Neurobiol Dis 44:84-91, 2011

243. Xia Y, Choi HK, Lee K: Recent advances in hypoxia-inducible factor (HIF)-1 inhibitors. Eur J Med Chem 49:24-40, 2012

244. Xu RH, Pelicano H, Zhou Y, Carew JS, Feng L, Bhalla KN, et al: Inhibition of glycolysis in cancer cells: a novel strategy to overcome drug resistance associated with mitochondrial respiratory defect and hypoxia. Cancer Res 65:613-621, 2005

245. Yang W, Wang L, Roehn G, Pearlstein RD, Ali-Osman F, Pan $\mathrm{H}$, et al: Small ubiquitin-like modifier 1-3 conjugation [corrected] is activated in human astrocytic brain tumors and is required for glioblastoma cell survival. Cancer Sci 104:70-77, 2013 (Erratum in Cancer Sci 104:70-77, 2013)

246. Yeo EJ, Ryu JH, Cho YS, Chun YS, Huang LE, Kim MS, et al: Amphotericin B blunts erythropoietin response to hypoxia by reinforcing FIH-mediated repression of HIF-1. Blood 107:916923, 2006

247. Yin S, Kaluz S, Devi NS, Jabbar AA, de Noronha RG, Mun J, et al: Arylsulfonamide KCN1 inhibits in vivo glioma growth and interferes with HIF signaling by disrupting HIF-1 $\alpha$ interaction with cofactors p300/CBP. Clin Cancer Res 18:6623-6633, 2012

248. Zagzag D, Zhong H, Scalzitti JM, Laughner E, Simons JW, Semenza GL: Expression of hypoxia-inducible factor 1alpha in brain tumors: association with angiogenesis, invasion, and progression. Cancer 88:2606-2618, 2000

249. Zhang W, Petrovic JM, Callaghan D, Jones A, Cui H, Howlett $\mathrm{C}$, et al: Evidence that hypoxia-inducible factor-1 (HIF-1) mediates transcriptional activation of interleukin-1beta (IL-1beta) in astrocyte cultures. J Neuroimmunol 174:63-73, 2006

250. Zhang Y, Liu Q, Wang F, Ling EA, Liu S, Wang L, et al: Melatonin antagonizes hypoxia-mediated glioblastoma cell migration and invasion via inhibition of HIF-1 $1 \alpha$. J Pineal Res 55:121-130, 2013 
251. Zhao S, Liu H, Liu Y, Wu J, Wang C, Hou X, et al: miR-143 inhibits glycolysis and depletes stemness of glioblastoma stemlike cells. Cancer Lett 333:253-260, 2013

252. Zhao YS, Zhu TZ, Chen YW, Yao YQ, Wu CM, Wei ZQ, et al: B-elemene inhibits Hsp90/Raf-1 molecular complex inducing apoptosis of glioblastoma cells. J Neurooncol 107:307-314, 2012

253. Zhong H, De Marzo AM, Laughner E, Lim M, Hilton DA, Zagzag D, et al: Overexpression of hypoxia-inducible factor 1alpha in common human cancers and their metastases. Cancer Res 59:5830-5835, 1999

254. Zhou Z, Liu F, Zhang ZS, Shu F, Zheng Y, Fu L, et al: Human rhomboid family-1 suppresses oxygen-independent degradation of hypoxia-inducible factor- $1 \alpha$ in breast cancer. Cancer Res 74:2719-2730, 2014

255. Zhu H, Woolfenden S, Bronson RT, Jaffer ZM, Barluenga S, Winssinger N, et al: The novel Hsp90 inhibitor NXD30001 induces tumor regression in a genetically engineered mouse model of glioblastoma multiforme. Mol Cancer Ther 9:26182626, 2010

256. Zundel W, Schindler C, Haas-Kogan D, Koong A, Kaper F, Chen E, et al: Loss of PTEN facilitates HIF-1-mediated gene expression. Genes Dev 14:391-396, 2000

257. Zwicker F, Kirsner A, Peschke P, Roeder F, Debus J, Huber PE, et al: Dichloroacetate induces tumor-specific radiosensitivity in vitro but attenuates radiation-induced tumor growth delay in vivo. Strahlenther Onkol 189:684-692, 2013

Manuscript submitted August 15, 2014.

Accepted September 23, 2014.

Please include this information when citing this paper: DOI: 10.3171/2014.9.FOCUS14496.

Address correspondence to: Randy L. Jensen, M.D., Ph.D., Department of Neurosurgery, Clinical Neurosciences Center, University of Utah, 175 N. Medical Dr. E, Salt Lake City, UT 84132. email: neuropub@hsc.utah.edu. 